\title{
Techno-economic environmental assessment of hybrid renewable energy system in India
}

\author{
K. M. Venkatachalam ${ }^{1}$, V. Saravanan ${ }^{2}$ \\ ${ }^{1}$ Research Scholar, Faculty of Electrical Engineering, Arunai Engineering College, Anna University, Tamil Nadu, India \\ ${ }^{2}$ Department of Electrical and Electronics Engineering, Arunai Engineering College, Anna University, Tamil Nadu, India
}

\section{Article Info}

Article history:

Received Dec 10, 2020

Revised Jul 9, 2021

Accepted Jul 23, 2021

\section{Keywords:}

Energy system

Hybrid renewable system

Optimization

Sensitivity analysis

Southern India

Techno-economic analysis

\begin{abstract}
The co-ordination of non-conventional energy technologies such as solar, wind, geothermal, biomass and ocean are gaining significance in India due to more energy requirements and high greenhouse gas emission. In this assessment, the sustainability of emerging the gird isolated hybrid solar photovoltaic (PV)/wind turbine (WT)/diesel generator (DG)/battery system for Arunai Engineering College, India building is evaluated. The technoeconomic and environmental research was inspected by HOMER Pro software by choosing the optimal combination depends on size of the components, renewable fraction, net present cost (NPC), cost of energy (COE) and greenhouse gas (GHG) emission of the hybrid system. From the acquired outcomes and sensitivity investigation, the optimal PV-WT-DGbattery combination has a NPC of $\$ 28.944 .800$ and COE $\$ 0.1266 / \mathrm{kWh}$, with an operating cost of $\$ 256.761$ year. The grid isolated hybrid system is environmentally pleasant with a greenhouse gas emission of $2.692 \mathrm{~kg} / \mathrm{year}$ with renewable fraction of $99.9 \%$.
\end{abstract}

This is an open access article under the CC BY-SA license.

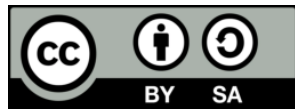

\section{Corresponding Author:}

K M. Venkatachalam

Research Scholar

Faculty of Electrical Engineering

Arunai Engineering College, Anna University

Tiruvannamalai 606 603, Tamil Nadu, India

Email: kmvpeee@gmail.com

\section{INTRODUCTION}

Growth of population, globalization and the progression in innovation, builds the utilization in energy and the emission of a significant greenhouse gas (GHG), carbon dioxide $\left(\mathrm{CO}_{2}\right)$ in the environment. In present days, the electric energy is mostly generated by conventional energy sources, for example, lignite, diesel and nuclear based energy sources. The fossil fuel based electric energy generation system derivatives drives two major issues, their consumption in nature and $\mathrm{CO}_{2}$ level in air prompting an unnatural weather change. Over the nation the non-renewable sources based electricity generation and consumer lines are integrated in a single grid. This structure of action ends up being advantageous for different spots, though, remote spaces suffer from restricted accessibility of electricity or no accessibility by any means, where the energy demand is less and the accessibility of petroleum products is far away from the heap request. The augmentation of grid such places bring about high establishment costs, less energy demand for most of the time. This is the place renewable energy sources (RES) coming to picture given their preferences, for example, accessibility at remote zones, unimportant contamination to the earth and less operating cost. International energy agency (IEA) forecasts that practically $30 \%$ of the electricity will produce from renewable sources by year 2020 [1]. 
According to Satsangi et al. [2] India has an average solar radiation (SR) is $4.9 \mathrm{kWh} / \mathrm{m} 2 /$ day with an average sunshine of 7.0 hours in a day. In India the SR is ranges from 3.9 to $5.6 \mathrm{kWh} / \mathrm{m} 2 /$ day depending upon climatic condition and locations [3]-[7], with the north-western borders facing grater solar radiation. It is additionally evaluated that India has average wind speed (WS) of $6.58 \mathrm{~m} / \mathrm{s}$ and the WS ranges from 3.5 to $9.75 \mathrm{~m} / \mathrm{s}$ from northern border to southern border, with southern coastal region experienced the highest wind speed of $9.75 \mathrm{~m} / \mathrm{s}$ [8]-[10]. Different investigations have recommended the arrangement of solar photovoltaic, wind turbine, fuel cell and other renewable energy sources for electric energy generation in different places in India [11]-[14]. These renewable energy sources are without contamination sources with zero natural effect. They are unreservedly accessible also, liberated from GHG emission [15]-[17]. While several works utilized the single renewable energy source based power generation system, other thought about the utilization of hybrid electric system by connecting solar photovoltaic (PV), wind turbine, fuel cell, biomass and utility grid. Some places the diesel generator (DG) and batteries were utilized as a backup generator and storage device for provide reliable and efficient energy to the load demands [18]-[22]. Whereas the grid supply is not accessible places like villages and remote areas, the diesel generator integrated hybrid system is preferred. The hybrid renewable energy system is chosen for reason that increase the overall reliability, reduce the components of electric system which may reduce the initial investment price of the system [23]-[26]. There is likewise the impact of climate condition because of variances in wind speed and solar radiation. Wind and solar based renewable system is established in various pieces of the world have required the growth and uses of a few optimization models and simulation tools for techno-economic and environmental feasibility investigation of various hybrid structures [27]-[32]. In India, many of the investigation were done in different pieces of the nation on grid isolated hybrid system for power optimization by using HOMER Pro simulation tool [12], [14]. The vast majority of the examinations concentrated on the utilization of hybrid RES for increase the productivity, while adjusting the impact of instability in the renewable energy sources [33], [34].

A few examinations have been done in different pieces of the world to survey the techno-economic and environmental analysis of different hybrid electric system. Ghenai and Bettayeb [16] examined the various combination of hybrid PV/fuel cell/DG energy system. They show that standalone system is a high renewable fraction, feasible economic with environmental friendly system for university building in Sharjah. Al-Hamadani [35] analyzed the hybrid diesel/PV/wind/battery systems under Iran climate conditions for nonresidential consumers. The hybrid system was analyzed on the basis of size of the PV panels and wind turbine, cost of energy and renewable fraction under with and without battery connected conditions. Hossain et al. [21] identified three rural places in Colombia, estimated the load demands and optimized the off-grid hybrid renewable energy system using HOMER. They demonstration that combination of hybrid PV/wind turbine (WT)/diesel is a capital cost, net present cost (NPC), and cost of energy (COE). In another study, Fodhil et al. [36] explored the optimal power and analysis the sensitivity of hybrid PV-DG-battery electric system by applying particle swarm optimization (PSO) techniques and HOMER software for rural electrification in Algeria. In Bangladesh, techno-economic feasibility assessment was proposed to fulfill the $248 \mathrm{kWh} /$ day energy demand for remote community using standalone hybrid photovoltaic/wind turbine/diesel generator/biogas generator/battery system by Das et al. [37]. In this standalone hybrid system greenhouse gas emission was compared with diesel based and grid connected system. Duman and Güler [38] developed an off-grid solar photovoltaic system for the application of light-emitting diode (LED) road light. They declared that the proposed model is acceptable decision for both financially and environmentally. AlHamadani [35] implemented a comparative feasibility investigation of grid integrated and isolated systems under southern Iran climate conditions. The optimal sizing of photovoltaic module, wind and batteries and also annual load growth by using HOMER simulation tool. Li et al. [39] estimated the housing estate loads in china and locate the optimal design of hybrid system utilizing HOMER. The results shows cost optimal, emission of pollution for hybrid solar PV/DG/battery system.

The techno-economic and feasibility analysis was completed in Dongola by Elkadeem et al. [40] to analyze the techno-economic of a hybrid PV/WT/DG/converter/battery system in providing power for agriculture and irrigation area. The examination uncovered the optimal design and economically reasonable with levelized COE and NPC of $0.387 \$ / \mathrm{kWh}$ and $24.16 \mathrm{M} \$$ respectively. The greenhouse gas emission is $95 \%$ is reduced to equate with only diesel system. A techno-economic examination of grid isolated hybrid photovoltaic/DG/battery system was analyzed in place of household load demand in Urunqi, China by Li and $\mathrm{Yu}$ [41]. A numerous models which incorporates fixed axis, one axis and two axis solar tracking systems, were dissected in the investigation. The optimal arrangement as far as cost of energy was the fixed axis solar tracking system ranges between $1.319 \$ / \mathrm{kWh}$ and $2.847 \$ / \mathrm{kWh}$. A technical and relative investigation of grid connected hybrid renewable energy system was carried out by Islam [42] for a large office building in Southeastern in France. The hybrid PV/utility grid system was seen as the $43 \%$ energy consumption is reduced from utility grid and also minimized the $90 \%$ of greenhouse gas emission. Shahzad et al [43] also 
assessed off grid hybrid solar-biomass system for provide electricity for rural areas in Pakistan. In this report the system initial capital cost and NPC are calculated as PKR 2.64 M and PKR 4.48 M respectively and also electricity provide at COE $5.51 \mathrm{PKR} / \mathrm{kWh}$ for the application of agricultural purposes. The performance of hybrid solar photovoltaic/DG/battery in Sabah, Malaysia by Halabi et al. [44] using HOMER simulation tool. The outcomes shows the hybrid photovoltaic/DG/battery system configuration is the best optimal design compared to overall configuration. Renewable fraction of the system values varied like $0 \%, 39.89 \%, 42.38 \%$, $59.21 \%, 86.90 \%$ and $100 \%$ depends upon different configuration of the hybrid system.

The related investigations talked about give a good foundation to the current examination by introducing different techno-economic contextual investigations carried out in many countries. For the examinations reported in India, the gotten cost of energy is more because wrong selection of equipment and components for the feasibility investigation. A large portion of the investigations concentrated on NPC particularly in India contextual analyses. Accordingly, in this examination, HOMER Pro simulation software was used to define the optimal design of hybrid solar photovoltaic/wind/diesel/battery in southern region of India, Tiruvannamalai. It is evaluates the techno-economic analysis depends on the minimal NPC and COE with less environmental pollution effects. The various configuration were simulated and the optimal configuration for the investigation place is the hybrid PV/WT/DG-battery with a NPC and COE are $\$ 28.944 .800$ and $0.1266 \$ / \mathrm{kWh}$ in that order.

\section{STUDY AREA AND LOAD PROFILE DESCRIPTION}

The grid isolated hybrid PV/WT/DG-battery is designed to make available electricity for Arunai Engineering College (Educational Institution) in Velu Nagar village, Tiruvannamalai with latitude $12^{0} 11.6^{\prime} \mathrm{N}$ and longitude $79^{0} 5.0^{\prime}$ E. The Institution is located in North-West region of Tamilnadu and located in western mountainous hills, which has huge amount of solar potential and wind potential.

The Arunai Engineering College was established in the year of 1993, total area of around 105.50 sq.m. Spanning area for academic, hostels, playground and amenities purposes. The institution consists of several buildings and each building consists of three to four floors. The most of the buildings are used for the academics purpose and few buildings are used for the hostel and administrative purposes. The electricity is needs for academics, administrative and hostel buildings for various electrical appliances at different time duration. The academics and administrative buildings energy consumption is relatively high due to more number of lights, air conditioner, lifts, computers and electrical motors at time duration between from 8.00 am to $5.30 \mathrm{pm}$. In hostel buildings mostly light loads, air coolers and water heater are consuming electrical energy at time duration between from $5.00 \mathrm{pm}$ to $9.00 \mathrm{am}$.

The total load and energy consumption of the administrative building is $19.8794 \mathrm{~kW}$ and energy consumption $158.873 \mathrm{kWh} /$ day, while the total load and energy consumption for academic and hostel buildings are $355.8785 \mathrm{~kW}$ and $1490.9312 \mathrm{~kW}, 2649.719 \mathrm{kWh} /$ day and $8527.0108 \mathrm{kWh} /$ day as presented in Table 1. The overall three buildings total energy consumption per day, peak load and average energy consumption are $11335.5128 \mathrm{~kW} /$ day, $1,769.87 \mathrm{~kW}$ and $472.31 \mathrm{~kW} /$ day with a load factor of $0.27,15 \%$ hour-hour and $10 \%$ day to day random variable were used to enable the load data to have some degree of variability at different times of the year. The load data is served into the HOMER software for the graphical representation of the hourly and monthly load profiles as illustrated in Figure 1.

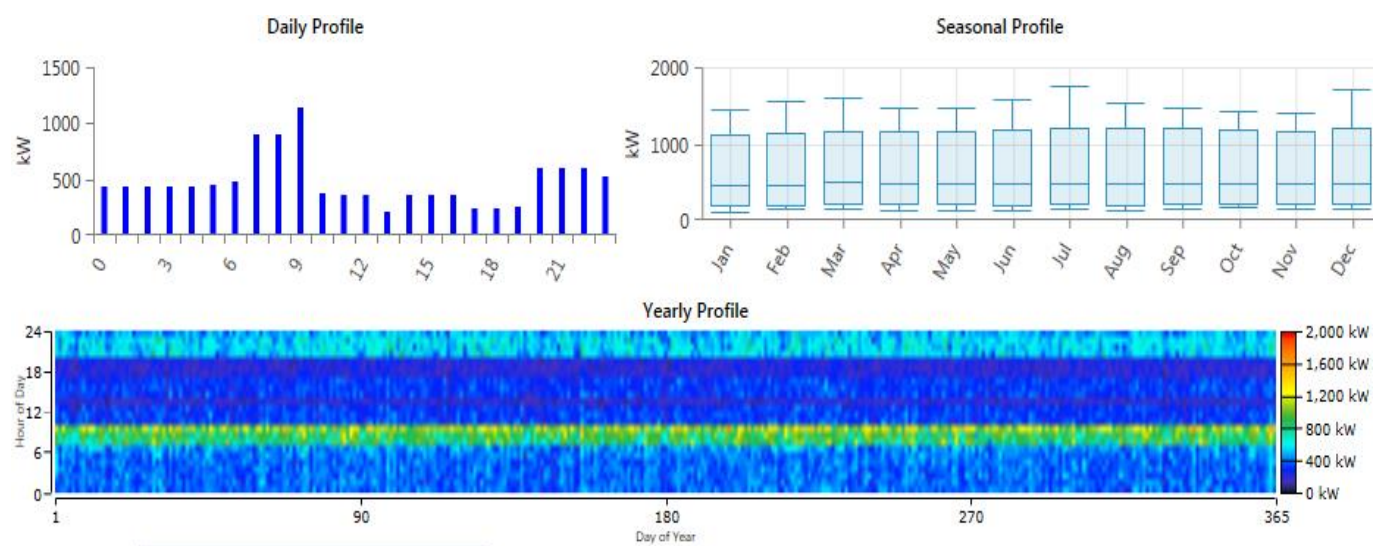

Figure 1. The daily and monthly electric load profile of Arunai Engineering College 
Table 1. The estimated electric load demand profile for Arunai Engineering College

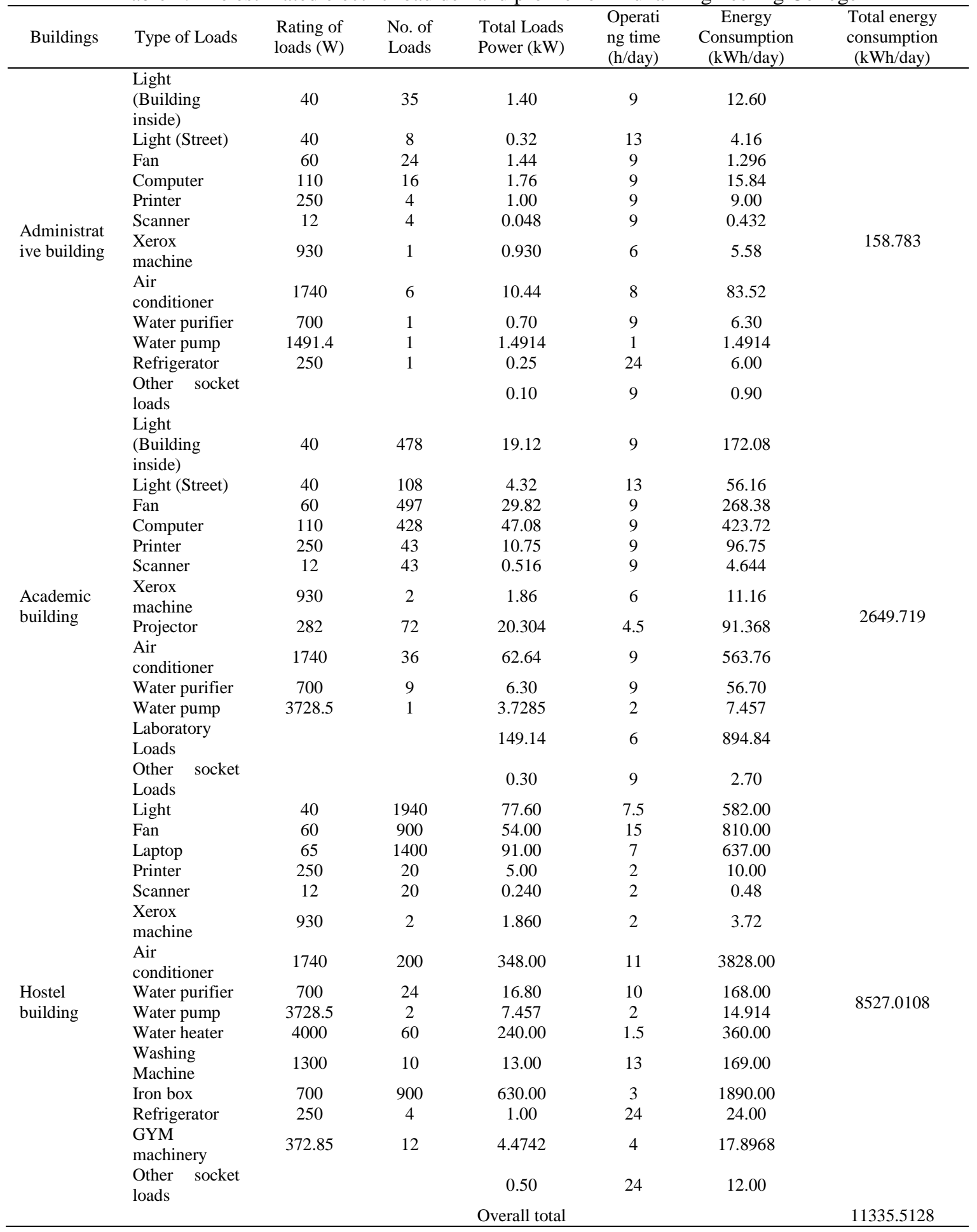

\section{SOLAR AND WIND POTENTIAL ASSESSMENT}

To design a solar PV system, the information on the SR and clearness index of the particular site is required. The openness of this solar potential is dictated by the accessibility of enough daylight hours in the zone [45]. For this evaluation, [46] the information utilized for the investigation was acquired from national aeronautics and space administration (NASA) utilizing the latitude and longitude of the area.

The chose area is in Tiruvannamalai arranged at latitude $12^{0} 11.6^{\prime} \mathrm{N}$ and longitude $79^{0} 5.0^{\prime} \mathrm{E}$ with the forecast daily average SR is $5.14 \mathrm{~kW} / \mathrm{m}^{2} /$ day. The twenty two years the average value of the solar data was gained from NASA by means of HOMER Pro software, the solar data information comprising of the 
clearness index and solar radiation ranges from 0.454 to 0.634 and $3.99 \mathrm{~kW} / \mathrm{m}^{2} / \mathrm{day}$ to $6.43 \mathrm{~kW} / \mathrm{m}^{2} / \mathrm{day}$ respectively as introduced in Figure 2. The long stretch of November has the least SR is $3.99 \mathrm{~kW} / \mathrm{m}^{2} / \mathrm{day}$ and the period of March has the most elevated SR estimation of $6.43 \mathrm{~kW} / \mathrm{m}^{2} / \mathrm{day}$. In any case, the month having least SR is still the solar system can be used to generate electricity.

Wind is another renewable resource that can be tackled for power generation. Wind turbines are combined with inbuilt generators which transforms the wind energy into electrical energy [9]. To generate effective electrical energy from the wind system, the evaluation place must have the essential wind speed to be driving the wind turbine. The non-identical wind turbines are exist for electric power generation and can work at different wind speed be decided by manufacturers, the wind speed for wind turbine activity may differ between $2.5 \mathrm{~m} / \mathrm{s}$ cut-in WS and $25 \mathrm{~m} / \mathrm{s}$ cut-out WS [10]. In this evaluation, the average wind speed of the Assam Engineering College (AEC) campus location $3.29 \mathrm{~m} / \mathrm{s}$ at $50 \mathrm{~m}$ height. The WS changes between 2.65 and $3.95 \mathrm{~m} / \mathrm{s}$ for the whole year in this location [46]. The information utilized for this investigation was acquired from NASA by means of HOMER Pro software, twenty two years average wind speed information changes between 2.65 and $3.95 \mathrm{~m} / \mathrm{s}$ as introduced in Figure 3. There is lower WS the month of November having an average WS of $2.65 \mathrm{~m} / \mathrm{s}$ and higher WS of $3.95 \mathrm{~m} / \mathrm{s}$ during the period of May. However, the average wind speed of the investigation place falls inside the necessary wind speed that can be utilized to exploit energy to generate electricity.

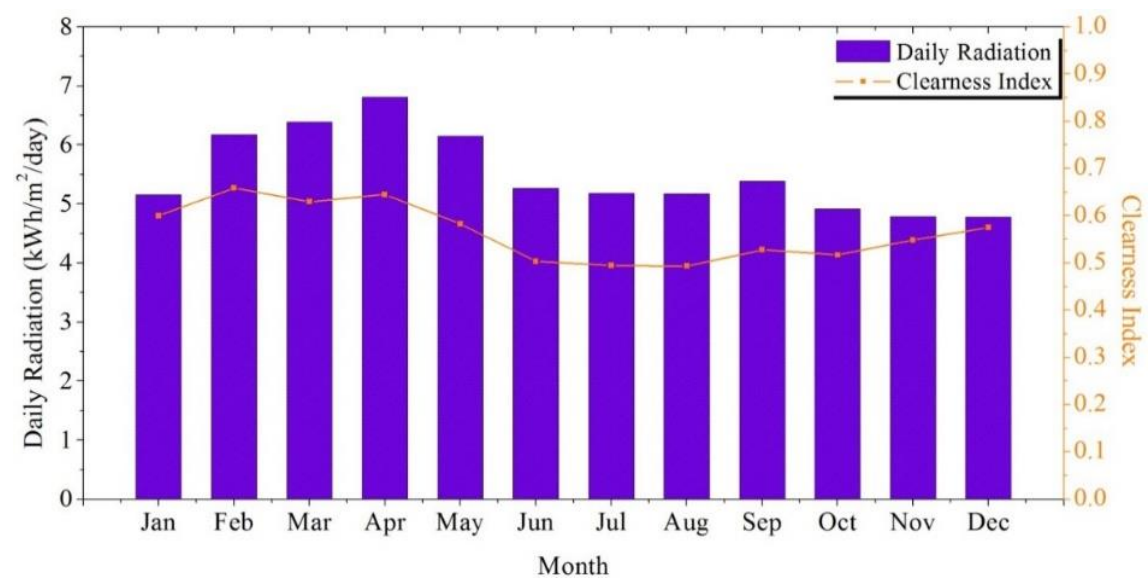

Figure 2. Monthly average solar radiation and clearness index in Arunai Engineering College

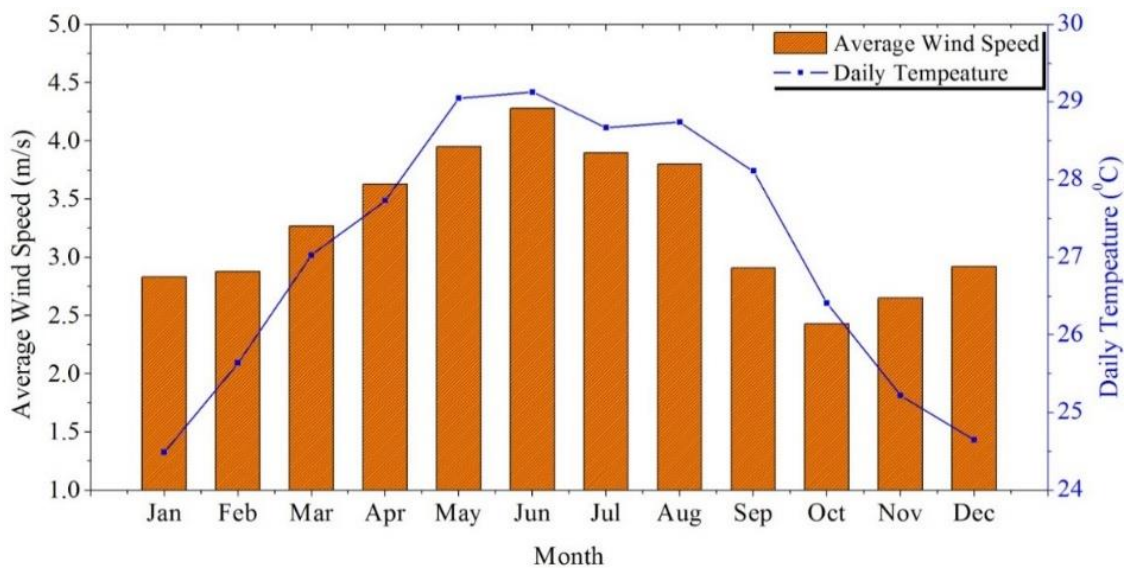

Figure 3. Monthly average wind speed and temperature in Arunai Engineering College

\section{DESIGN AND SPECIFICATION DESCRIPTION OF HYBRID SYSTEM}

The grid isolated hybrid electric energy system comprising of photovoltaic arrays, wind generator, diesel generator, battery, a converter, DC bus, AC bus and electric load as appeared in Figure 4. The batteries are used to store the surplus energy that can utilized while the solar photovoltaic and wind generator systems

Techno-economic environmental assessment of hybrid renewable energy system in ... (Venkatachalam $\mathrm{K} M$ ) 
are not capable to encounter the load demand, while the diesel generator fills in as a reinforcement power flexibly when the solar, wind and the batteries also not capable to encounter load requirements. Various combination of hybrid frameworks have been proposed in various pieces of the globe dependent on the accessible renewable resources in those regions [47], [48]. In India, a few investigations have likewise been completed utilizing the accessible renewable resources [1], [11], [12], [27]. In this assessment HOMER Pro is utilized to design the hybrid PV-WT-DG-battery system and analysis the techno-economic feasibilities, optimization of power and sensitivity. It simulates various framework designs utilizing sources of info, for example, climate information for the chose location, component technical specifications, cost of the components and load information. HOMER Pro software simulates the wide range of framework arrangements and chooses optimal design with the less NPC and levelized COE. Figure 5 presents the architecture of the HOMER Pro software for techno-economic assessment.

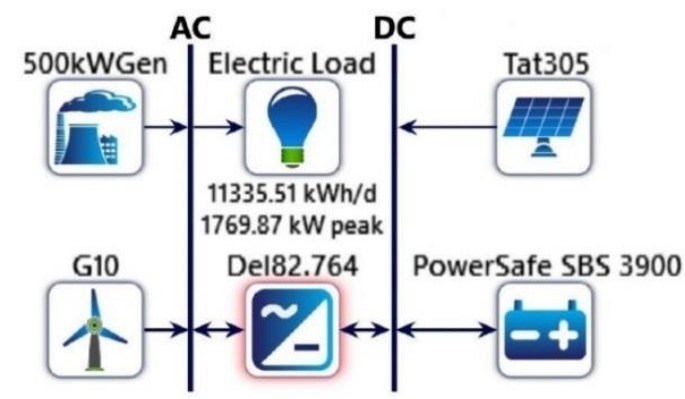

Figure 4. Schematic diagram of hybrid PV-WT-DG-battery system

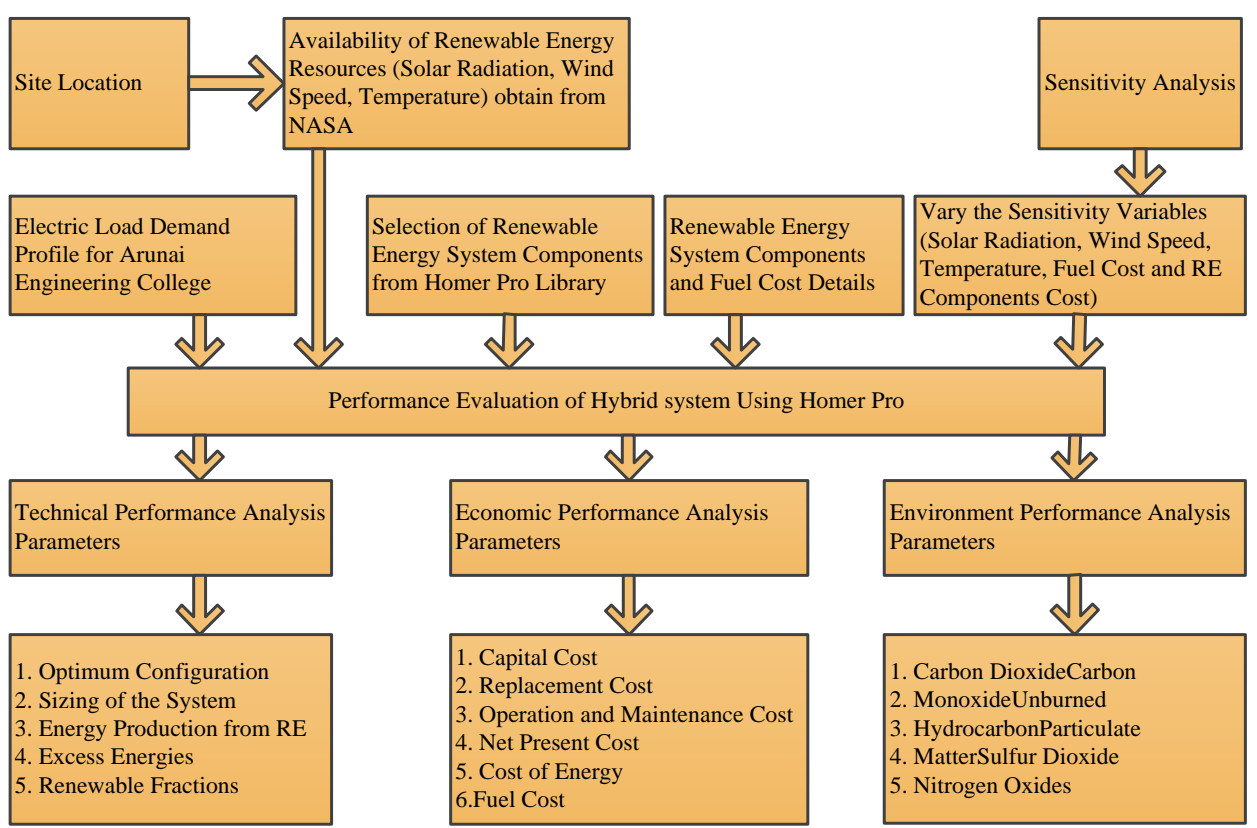

Figure 5. Architecture of the HOMER Pro operation for Arunai Engineering College

\subsection{Output power of the solar photovoltaic array}

The output power of the solar photovoltaic array is calculated by (1) [12], [35] in HOMER Pro. 


$$
P_{P V}=Y_{P V} f_{P V}\left(\frac{G_{T}}{G_{T, S T C}}\right)\left[1+\alpha_{p}\left(T_{c}-T_{C, S T C}\right)\right]
$$

Where $Y_{P V}, f_{P V}, G_{T}$ and $G_{T}$, STC are the PV array rated capacity, derating factor, actual $S R$ and test condition SR respectively. $T_{c}$ and $T_{c}, S T C, \alpha_{p}$, are the actual and standard test condition cell temperature and temperature coefficient respectively.

In this assessment, Tat305TP305LBZ, rating of $0.305 \mathrm{~kW}_{\mathrm{p}}$ flat plate photovoltaic panel is selected and its capital cost, operation and maintenance cost $(\mathrm{O} \& \mathrm{M})$, replacement cost (RC) and other technical parameters details are introduced in Table 2. The maximum capacity of the photovoltaic system considered for this assessment is $3500 \mathrm{~kW}$.

Table. 2. Technical and economic parameters details of solar photovoltaic system

\begin{tabular}{ll}
\hline Parameter & Specification \\
\hline Model & Tat305TP305LBZ (Tat305) \\
Manufacturer & Tata Power Solar Systems \\
Panel Type & Flat Plate \\
Rated Capacity $(\mathrm{kW})$ & 0.305 \\
Operating Temperature $\left({ }^{\circ} \mathrm{C}\right)$ & 48.8 \\
Temperature Coefficient & -0.438300 \\
Efficiency $(\%)$ & 13 \\
Capital cost $(\$ / \mathrm{kWp})$ & 1,500 \\
Replacement cost $(\$ / \mathrm{kWp})$ & 1,200 \\
O\&M cost $(\$ / \mathrm{kWp} /$ year) & 25 \\
Derating Factor $(\%)$ & 85 \\
Life time (years) & 25 \\
\hline
\end{tabular}

\subsection{Output power of the wind generator}

The WS in wind turbine hub was assessed by HOMER Pro as (2) [12], [35].

$$
U_{\text {hub }}=U_{\text {anem }} \frac{\ln \left(Z_{\text {hub }} / Z_{0}\right)}{\ln \left(Z_{\text {anem }} / Z_{0}\right)}
$$

Where $\mathrm{U}_{\text {anem }}$ is a WS, $\mathrm{Z}_{\text {anem }}$ is a height of the anemometer, $\mathrm{Z}_{\text {hub }}$ is a height of the hub and $\mathrm{Z}_{0}$ is a length of the surface. The wind system output power is determined as (3).

$$
P_{W T G}=\left(\frac{\rho}{\rho_{0}}\right) P_{W T G, S T P}
$$

Where $\mathrm{P}_{\mathrm{WTG}}$ STP is a output power of the wind turbine at standard conditions are determined utilizing the wind turbines output power curve, $\rho$ is actual air density and $\rho_{0}$ is air density at standard conditions.

In this assessment selected a generic $10 \mathrm{~kW}$ wind turbine framework which is chosen dependent on the cut-in and cut-out WS of the wind turbine, height of WT and cost of the WT. Figure 6 represents the characteristic curve of the WT. The technical parameters of the WT, CC, RC, O \& M cost are introduced in Table 3.

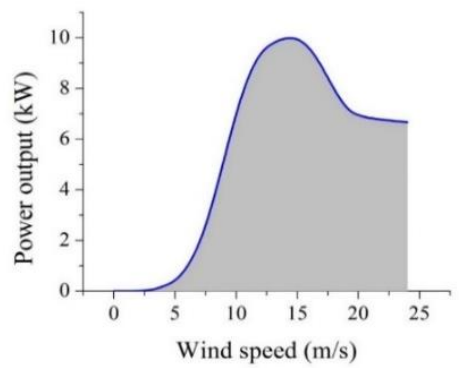

Table 3. Technical and economic parameters details

\begin{tabular}{ll}
\multicolumn{2}{c}{ of wind turbine } \\
\hline Parameter & Specification \\
\hline Model & Generic 10 kW (G10) \\
Manufacturer & Generic \\
Rated Capacity $(\mathrm{kW})$ & 10 \\
Capital cost $(\$)$ & 45.000 \\
Replacement cost $(\$)$ & 45.000 \\
O\&M cost (\$/year) & 150 \\
Hub Height (m) & 24 \\
Life time (years) & 20 \\
\hline
\end{tabular}

Figure 6. Characteristic curve of the $10 \mathrm{~kW}$ generic wind turbine 


\subsection{Diesel generator}

The essential back-up power source, diesel generators have been generally utilized in hybrid power generation system so as to improve the reliability of the system. In this assessment, $500 \mathrm{~kW}$ diesel generators were chosen to fulfill a peak load demand of $1769.87 \mathrm{~kW}$ with $10 \%$ of operating reserve capacity. The fuel utilization of the DG is identified with the rated power and output powers, which can be determined as (4) [35].

$$
F_{D G}=a_{P D G-\text { rated }}+b_{P D G-o u t}
$$

Here, $\mathrm{P}_{\mathrm{DG}-\mathrm{rated}} \mathrm{P}_{\mathrm{DG}-\mathrm{out}}$ are the generator rated power and generator output power. Efficiency of the diesel generator is determined by utilizing the derived equation [35].

$$
\eta_{D G}=\frac{3.6 P_{D G-o u t}}{\rho_{f u e} F_{D G} H_{L}-f u e}
$$

Here, $\rho_{\text {fue }}$ is the density of the fuel $\left(\mathrm{kg} / \mathrm{m}^{3}\right)$ and $\mathrm{H}_{\mathrm{L}-f u e}(\mathrm{MJ} / \mathrm{kg})$ is the lower warming of the fuel. The DG efficiency curve as presented in Figure 7 and technical parameters of the diesel generator, CC, RC, O \& $\mathrm{M}$ cost, fuel consumption and other parameters are introduced in Table 4.

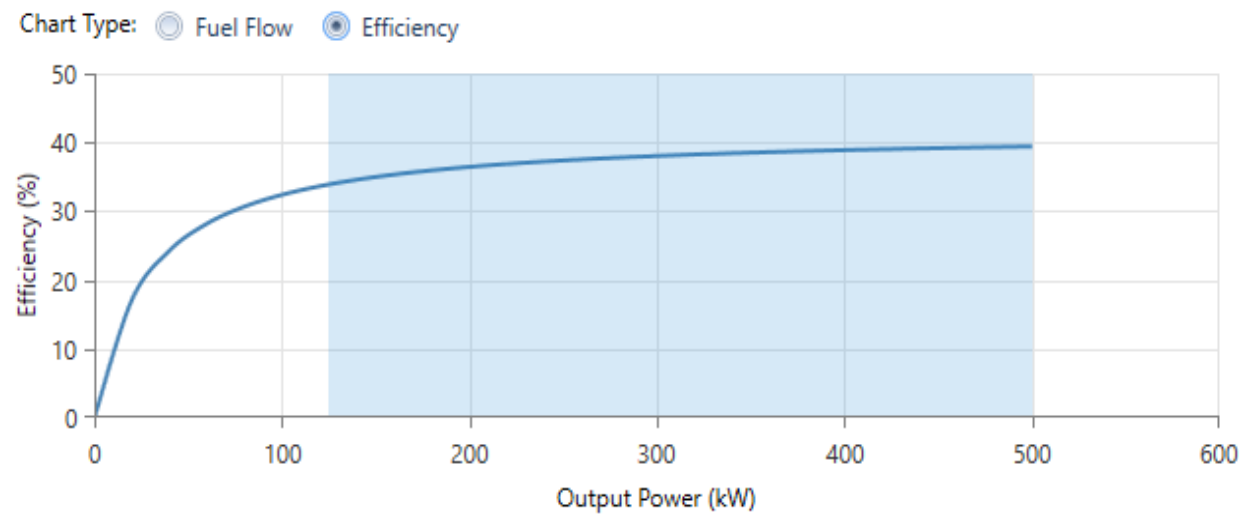

Figure 7. Efficiency curve of $500 \mathrm{~kW}$ diesel generator

Table 4. Technical and economic parameters details of diesel generator

\begin{tabular}{ll}
\hline Parameter & Specification \\
\hline Model & Generic $500 \mathrm{~kW}$ Fixed Capacity Genset \\
Capacity $(\mathrm{kW})$ & 500 \\
Fuel & Diesel \\
Fuel curve intercept $(\mathrm{L} / \mathrm{hr})$ & 7 \\
Fuel curve slop $(\mathrm{L} / \mathrm{hr} / \mathrm{kW})$ & 0.244 \\
$\mathrm{CO}(\mathrm{g} / \mathrm{L}$ fuel $)$ & 13.566 \\
Unburned $\mathrm{HC}(\mathrm{g} / \mathrm{L}$ fuel $)$ & 0.72 \\
Particulate $(\mathrm{g} / \mathrm{L}$ fuel) & 0.116 \\
Fuel sulfur converted to PM $(\%)$ & 2.2 \\
NOx $(\mathrm{g} / \mathrm{L}$ fuel) & 2.60 \\
Lower heating value $(\mathrm{MJ} / \mathrm{kg})$ & 43.2 \\
Density $\left(\mathrm{kg} / \mathrm{m}^{3}\right)$ & 820 \\
Carbon content $(\%)$ & 88 \\
Sulfur content $(\%)$ & 0.4 \\
Capital cost $(\$)$ & 200.000 \\
Replacement cost $(\$)$ & 200.000 \\
O\&M cost $(\$ / o p . h o u r)$ & 5 \\
Minimum load ratio $(\%)$ & 25 \\
Fuel Price $(\$ / \mathrm{L})$ & 0.86 \\
Life time (hours) & 15.000 \\
\hline
\end{tabular}




\subsection{Battery charge and discharge power}

A battery maximum charge power $\left(\mathrm{P}_{\text {batt, cmax }}\right)$ is measured using HOMER Pro is the base of three distinct limits on the batteries $\mathrm{P}_{\text {batt, } \mathrm{cmax}}$, to be specific [12], [35].

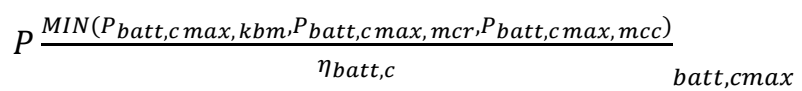

Where,

$$
\begin{aligned}
& P_{\text {batt }, c \max , k b m}=\frac{k Q_{1} e^{-k \Delta t}+Q k c\left(1-e^{-k \Delta t}\right)}{1-e^{-k \Delta t}+c\left(k \Delta t-1+e^{-k \Delta t}\right)} \\
& P_{b a t t, c \max , m c r}=\frac{\left(1-e^{-k \Delta t}\right)\left(Q_{\max }\right.}{\Delta t} \\
& P_{b a t t, c \max , \text { mcc }}=\frac{N_{b a t t} I_{\max } V_{\max }}{1000} \\
& \eta_{\text {batt }, c}=\sqrt{\eta_{\text {batt }, r t}}
\end{aligned}
$$

Where, $\mathrm{Q}_{1}, \mathrm{Q}$ and $\mathrm{Q}_{\max }$ are the accessible energy, sum of energy and capacity of the battery bank respectively. $\mathrm{c}, \mathrm{k}$ and $\alpha_{\mathrm{c}}$ are the capacity ratio, constant rate and maximum rate of charge. Additionally, $\mathrm{t}$, $\mathrm{N}_{\text {batt, }} \mathrm{I}_{\max }, \mathrm{V}_{\text {nom, }} \mathrm{g}_{\text {batt, c }}, \mathrm{g}_{\text {batt, rt }}$ are step time, battery quantity, battery nominal voltage, battery charge efficiency and round-trip efficiency respectively. The maximum discharge power $\left(\mathrm{P}_{\text {batt, dmax }}\right)$ of the battery banks as calculated as (11), (12) and (13).

$$
\text { Pbatt, } d_{\text {batt,d max, } \text { kbm }_{\text {batt,dmax }}}
$$

Where,

$$
\begin{aligned}
& P_{b a t t, d \max , k b m}=\frac{-k Q 1^{-k \Delta t}{ }^{-k \Delta t} \max }{1-e^{-k \Delta t}+c\left(k \Delta t-1+e^{-k \Delta t}\right)} \\
& \eta_{b a t t, d}=\eta_{b a t t, d}
\end{aligned}
$$

In this assessment, a PowerSafe SBS 3900 lead-acid battery with $12 \mathrm{~V}$, maximum capacity is $4300 \mathrm{Ah}$ and nominal capacity of $51.6 \mathrm{kWh}$ is selected for simulation. The round-trip efficiency of this battery is $97 \%$ with minimum state of charge (SOC) value is $30 \%$. The technical and economic parameters details are introduced in Table 5. Figure 8 shows the capital and replacement cost variation curve.

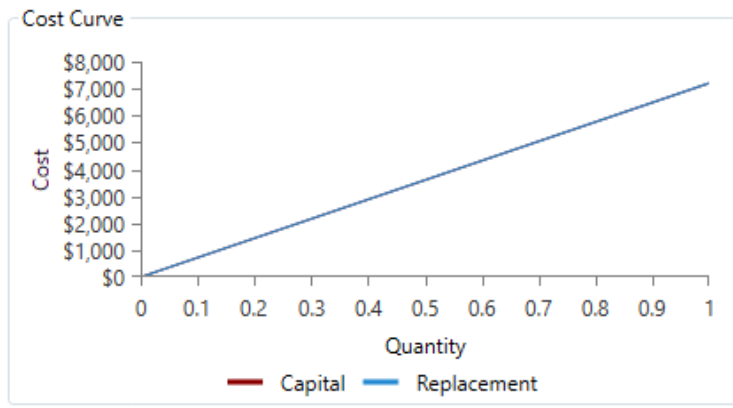

Figure 8. Cost curve of the PowerSafe SBS 3900 lead-acid battery
Table 5. Technical and economic parameters details

\begin{tabular}{ll}
\multicolumn{2}{c}{ of battery } \\
\hline Parameter & Specification \\
\hline Nominal voltage $(\mathrm{V})$ & 12 \\
Nominal capacity $(\mathrm{kWh})$ & 51.6 \\
Maximum Capacity (Ah) & $4.3 \mathrm{E}^{+03}$ \\
Capacity ratio & 0.298 \\
Rated constant (1/hr) & 1.95 \\
Roundtrip efficiency (\%) & 97 \\
Maximum charge current (A) & $3.9 \mathrm{E}^{+03}$ \\
Maximum discharge current $(\mathrm{A})$ & $4.6 \mathrm{E}^{+03}$ \\
Maximum charge rate (A/Ah) & 1 \\
Capital cost (\$) & 7200 \\
Replacement cost (\$) & 7200 \\
O\&M cost (\$/year) & 0 \\
Throughput (kWh) & 55.134 .60 \\
Minimum SOC $(\%)$ & 30 \\
Life time (years) & 15 \\
\hline
\end{tabular}

\subsection{Converter}

There are two energy conversion in the electric system such as DC-AC and AC-DC conversion. Consequently, an inverter and rectifier are fundamental. In this assessment a Del82.764 converter, the 
rectifier had $100 \%$ limit comparative with the inverter and its efficiency was $98.5 \%$ and converter lifetime was 15 years. The converter technical and economical parameters are introduced in Table 6.

Table 6. Technical and economic parameters details of converter

\begin{tabular}{ll}
\hline \multicolumn{1}{c}{ Parameter } & \multicolumn{1}{c}{ Specification } \\
\hline Model & Del82.764 \\
Manufacturer & Delta Electronics \\
Capital cost $(\$ / \mathrm{kW})$ & 220 \\
Replacement cost $(\$ / \mathrm{kW})$ & 220 \\
O\&M cost $(\$ /$ year) & 10 \\
Efficiency $(\%)$ & 98.50 \\
Life time (years) & 15 \\
\hline
\end{tabular}

\subsection{Economic evaluation of the system}

The NPC includes transformation of every single yearly advantage and costs stream happening at various focuses in the existence time of the project to their current value counterparts and including them to get the overall worth everything being equal and expenses of the project which is mathematically composed as (14) [35].

$$
N P V=\sum_{t=1}^{N} \frac{R_{t}-C_{t}}{(1+i)^{t}}-I_{0}
$$

Here $R_{t}, C_{t}, I, I_{0}$ and $N$ are the income, expense, rate of interest, initial cost and project life time respectively. The COE is acquired by including up the net costs a yearly premise and partitions it by the yearly provided energy as (15).

$$
C O E=\frac{A C C+A R C+A M C+A G C}{A S E}
$$

Where,

$$
A C C=\frac{i(1+i)^{N}}{(1+i)^{N}-1} I_{0}
$$

It is an annual capital cost and replacement cost.

$$
A R C=\frac{i(1+i)^{N}}{(1+i)^{N}-1} I_{0} \sum_{n_{R}} \frac{C_{R}}{(1+i)^{t_{R}}}
$$

Where, $C_{R}$ is a replacement of the components, $t_{R}$ is a time of the replacement and $n_{R}$ is the no.of replacements during the existence time of the project. Likewise AGC and AMC are yearly net grid charge and maintenance cost, independently.

\subsection{Environmental evaluation of the system}

The GHG emission in hybrid PV-WT-DG-battery system results from the generation of electric power by the renewable resources and generators. For the diesel generator yearly $\mathrm{CO}_{2}$ emission is determined by using emission factor and yearly fuel utilization. For the grid integrated system, the emission level is calculated by using purchased net power from grid and its emission factor [35].

\section{OPERATION STRATEGY}

The grid isolated hybrid PV-WT-DG-battery system works in two principle techniques, specifically the cycle charging (CC) and load following (LF). The CC technique, the DG joined is utilized to supply power to the load and charge the battery bank simultaneously. While LF technique, the solar and wind turbines are serving demand simultaneously the battery bank charged by surplus power. In the occasion where the renewable power generation is not capable to encounter or inaccessible, the DG is arranged to attend the load. Figure 9 represents the operational flowchart for grid isolated hybrid PV/wind/diesel/battery system. The flow chart expresses the expresses overall power management of the system that is directs the flow of the energy in the hybrid system. For this assessment, the LF technique is implemented where just the renewable energy sources are utilized in charging the battery bank. 
The charged battery storage system attends to serve the load demand in the occasion where the renewable sources can't serve the load requirements. The diesel generator can possibly serve the load demand when both renewable sources and battery storage systems are couldn't meet the loads. This decreases helps in decreasing the surplus power generation and furthermore helps in reduce NPC of the framework. There are circumstances that the load can't be given by the RES because of weather conditions. For instance, when there is accessible SR, the solar photovoltaic supplies power to the load and surplus power is a charge to the battery bank, similarly goes to the wind system when there is accessible WS to drive the WT. At the point when the photovoltaic and wind generator sources are not capable to encounter the demand, the batteries which fill in as the capacity will flexibly the load demand until battery discharged to $30 \%$ of the minimum SOC. When battery is going to under $30 \%$ of SOC the generator consequently goes on to serve the load demand.

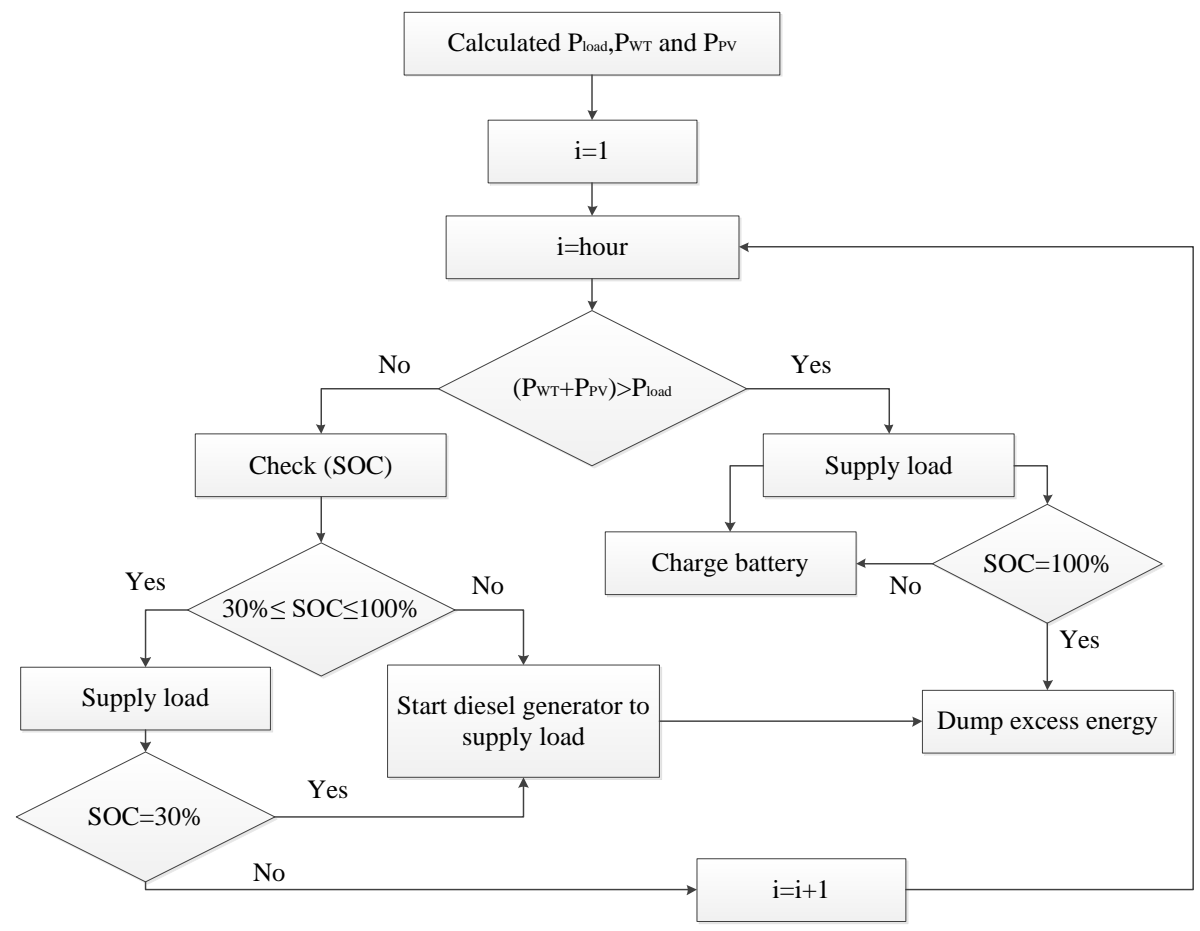

Figure 9. Operational flowchart for grid isolated hybrid PV/wind/diesel/battery system

\section{SIMULATION RESULTS AND DISCUSSION}

In this assessment designs a hybrid PV/WT/DG-battery electric system to attend the electric load requirements of Arunai Engineering College in Tiruvannamalai, Tamil Nadu, India. HOMER Pro simulation tool was employed to model the hybrid renewable energy system by determining the optimal system configuration using the Arunai Engineering College electric load profile, weather data and component details.

\subsection{Optimization analysis of the hybrid electric system}

HOMER Pro software categorized all the possible framework arrangements for the Arunai Engineering College. The classified optimal configuration for Arunai Engineering College with an annual average SR of $5.14 \mathrm{kWh} / \mathrm{m}^{2} /$ day and a fuel cost of $0.86 \$ / \mathrm{L}$ are appeared in Table 7 and Figure 10 . The optimization configurations are classified four kinds of power system with minimum NPC and COE as PVWT-DG-Battery, PV-DG-battery, PV-WT-battery and PV-battery.

For the optimal PV-WT-DG-battery design contains $3500 \mathrm{~kW}$ photovoltaic panels, $1 \mathrm{~kW}$ wind turbine, $500 \mathrm{~kW} \mathrm{DG}, 1.222$ quantity of batteries with $2.090 \mathrm{~kW}$ converters. It has the total NPC of $\$ 28.944 .800$ and COE of $\$ 0.1266 / \mathrm{kWh}$. For this design, the solar system has the higher capital expense followed by the batteries and the converter, the diesel generator has the least capital expense. In view of the NPC, the batteries have the higher NPC because of replacement cost followed by the solar photovoltaic and fuel cost of DG, the converter of the system has the minimum NPC. Table 8 presents the overview of the cash flow of the optimal setup investigated by various cost types. Table 8 presents the capital and

\footnotetext{
Techno-economic environmental assessment of hybrid renewable energy system in ... (Venkatachalam $\mathrm{K} \mathrm{M}$ )
} 
replacement expenses are main cost of the system which includes for the most part the batteries and the solar system, followed by the diesel cost. The operating and maintenance cost is extremely minimum due to considered the system is mainly supplied by the solar and wind sources, which has the less operating expenses.

Table 7. Optimal configurations of the hybrid electric system

\begin{tabular}{|c|c|c|c|c|c|c|c|c|c|c|c|c|}
\hline $\begin{array}{l}\text { Configura } \\
\text { tion }\end{array}$ & $\begin{array}{l}\text { PV } \\
(\mathrm{kW})\end{array}$ & $\begin{array}{l}\text { WT } \\
(\mathrm{kW} \\
)\end{array}$ & $\begin{array}{l}\text { DG } \\
(\mathrm{kW} \\
)\end{array}$ & $\begin{array}{l}\text { Batter } \\
\mathrm{y}\end{array}$ & $\begin{array}{l}\text { Convert } \\
\text { er }(\mathrm{kW})\end{array}$ & $\begin{array}{l}\mathrm{D} \\
\mathrm{S}\end{array}$ & $\begin{array}{l}\text { NPC } \\
(\$)\end{array}$ & $\begin{array}{l}\mathrm{COE} \\
(\$ / \mathrm{kWh})\end{array}$ & $\begin{array}{l}\text { Initial } \\
\text { cost }(\$)\end{array}$ & $\begin{array}{l}\text { Operating } \\
\text { cost } \\
(\$ / \text { year })\end{array}$ & $\begin{array}{l}\mathrm{RF} \\
(\%)\end{array}$ & $\begin{array}{l}\text { Total } \\
\text { fuel } \\
\text { (L/ye } \\
\text { ar) }\end{array}$ \\
\hline $\begin{array}{l}\text { PV-WT- } \\
\text { DG- } \\
\text { Battery }\end{array}$ & 3.500 & 1 & 500 & 1.222 & 2.090 & LF & $\begin{array}{l}28.944 \\
.800\end{array}$ & 0.1266 & $\begin{array}{l}14.753 .1 \\
14.69\end{array}$ & 256.761 .50 & 99.9 & 1027 \\
\hline $\begin{array}{l}\text { PV-DG- } \\
\text { Battery }\end{array}$ & 3.500 & & 500 & 1.239 & 1.946 & LF & $\begin{array}{l}28.981 \\
.140\end{array}$ & 0.1268 & $\begin{array}{l}14.798 .9 \\
39.66\end{array}$ & 256.590 .00 & 99.9 & 898 \\
\hline $\begin{array}{l}\text { PV-WT- } \\
\text { Battery }\end{array}$ & 3.500 & 1 & & 1.321 & 1.800 & $\begin{array}{l}\mathrm{C} \\
\mathrm{C}\end{array}$ & $\begin{array}{l}30.589 \\
.540\end{array}$ & 0.1338 & $\begin{array}{l}15.202 .1 \\
23.72\end{array}$ & 278.395 .30 & 100 & 0 \\
\hline $\begin{array}{l}\text { PV- } \\
\text { Battery }\end{array}$ & 3.500 & & & 1.325 & 1.811 & $\begin{array}{l}\mathrm{C} \\
\mathrm{C}\end{array}$ & $\begin{array}{l}30.601 \\
.110\end{array}$ & 0.1338 & $\begin{array}{l}15.187 .6 \\
60.64\end{array}$ & 278.866 .30 & 100 & 0 \\
\hline
\end{tabular}

Table 8. Cash flow summary of PV-WT-DG-battery configuration

\begin{tabular}{lllllll}
\hline Component & \multicolumn{1}{c}{ Capital $(\$)$} & Replacement $(\$)$ & O \& M $(\$)$ & Fuel $(\$)$ & Salvage $(\$)$ & Total $(\$)$ \\
\hline PV & 5.250 .000 & 0 & 4.836 .286 .48 & 0 & 0 & 10.086 .286 .48 \\
WT & 45.000 & 135.349 .19 & 8.290 .78 & 0 & -133.683 .47 & 54.956 .50 \\
DG & 200.000 & 0 & 2.210 .87 & 48.802 .59 & -781.635 .70 & 530.622 .23 \\
Battery & 8.798 .400 & 20.094 .909 .91 & 0 & 0 & -11.616 .796 .53 & 17.276 .513 .37 \\
Converter & 459.714 .69 & 1.049 .955 .14 & 1.154 .967 .24 & 0 & -606.975 .36 & 2.057 .661 .71 \\
System & 14.753 .114 .69 & 21.280 .214 .23 & 6.001 .755 .38 & 48.802 .59 & -13.139 .091 .06 & 28.944 .795 .83 \\
\hline
\end{tabular}

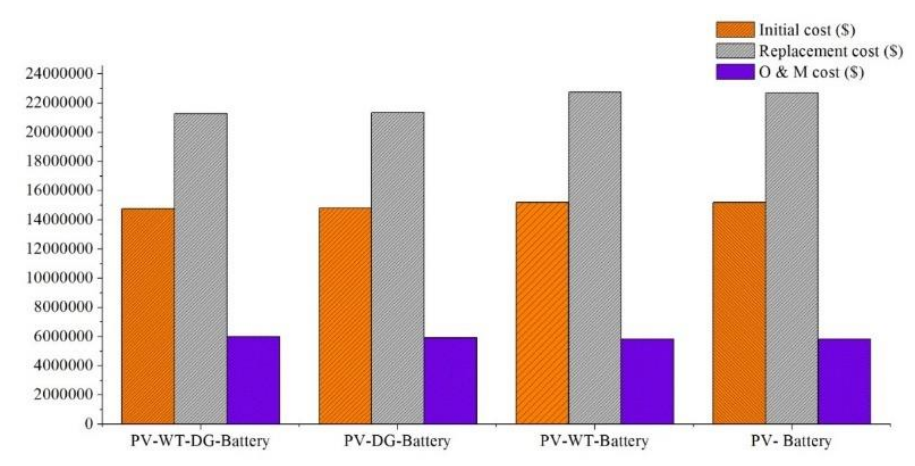

Figure 10. Optimal configurations of the hybrid system

\subsection{Economic analysis of the hybrid electric system}

HOMER Pro simulates various economic details. Table 7 introduced a correlation of the financial boundaries for every one of the classified configurations. The financial details are divided into initial cost, NPC, RC, and O \& M cost. The grid isolated PV-WT-DG-battery configuration has the minimum initial cost of $\$ 14.753 .114 .69$.

The hybrid PV-DG-battery has the second least initial cost of $\$ 14.798 .939 .66$. The other two PVWT-battery and PV-battery configurations have the highest initial cost of $\$ 15.202 .123 .72$ and \$15.187.660.64 respectively. The hybrid PV-DG-battery has the second minimum cost of \$14.798.939.66. Remaining two PV-WT-battery and PV-battery configurations have the maximum initial cost of $\$ 15.202 .123 .72$ and $\$ 15.187 .660 .64$ respectively. The configuration with the minimum $\mathrm{O} \& \mathrm{M}$ cost is the hybrid PV-WT-DG-battery system with operating cost of $\$ 6.001 .755 .38$. The following is the PV-DG-battery framework with $O \& M$ cost of $\$ 5.913 .860 .51$ and happens to be the setup with the higher $O \& M$ cost. The PV-WT-battery and PV-battery frameworks have the O \& $\mathrm{M}$ cost of \$5.839.278.84 and \$5.836.721.84 correspondingly. The hybrid PV-WT-battery arrangement has the higher replacement cost of \$22.762.503.97 which is because of more number of batteries and photovoltaic panels utilized in the design. PV-battery setup 
has the second higher replacement cost, followed by PV-DG-battery and PV-WT-DG-battery configurations with replacement cost of \$22.698.865.40, \$21.352.302.72 and \$21.280.214.23 correspondingly as shown in Table 7 and Figure 10. It is noticed that the design with the more number of batteries has the higher replacement cost because of more battery cost, it is in this way decided the quantity of batteries influences the expense of a framework. Furthermore, the total NPC and COE of all the feasible framework designs examined in Arunai Engineering College are demonstrated in Figure 11.

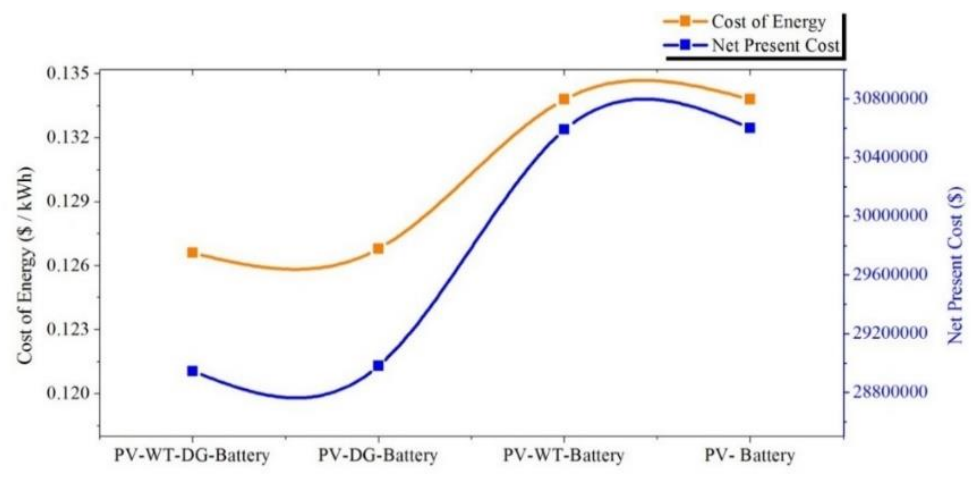

Figure 11. NPC and COE of all the feasible system configurations in Arunai Engineering College

\subsection{Output energy analysis of the hybrid electric system}

Various electric energy parameters of the hybrid renewable system were also analyzed. From the outcomes acquired from HOMER Pro, the hybrid PV-WT-DG-battery design has the maximum energy generation is $5.103 .072 \mathrm{kWh} /$ year with annual utilization of $4.136 .751 \mathrm{kWh} /$ year and surplus energy of $847.231 \mathrm{kWh} /$ year. The hybrid PV-DG-battery setup has the second higher energy generation is $5.100 .836 \mathrm{kWh} /$ year with annual utilization of 4,136,735 kWh/year and surplus energy of $844,944 \mathrm{kWh} /$ year that is utilized to charge the batteries. The energy of $99 \%$ is generated from the photovoltaic system with $1.01 \%$ generated from the diesel generator. The PV-WT-battery and PV-battery arrangements have power generation of $5.099 .094 \mathrm{kWh} /$ year and $5.096 .520 \mathrm{kWh} /$ year surplus energy of $843.106 \mathrm{kWh} /$ year and $840.486 \mathrm{kWh} /$ year correspondingly. These two setups have the minimum energy generation and they fulfill the annual energy utilization of $4.136 .728 \mathrm{kWh} /$ year and $4.136 .734 \mathrm{kWh} / \mathrm{year}$ as introduced in Table 9. Moreover, Figure 12 and Figure 13 shows the month average energy generation, surplus energy from the optimal hybrid PV-WT-DG-Battery system in Arunai Engineering College.

Table 9. Comparison of output energy in hybrid electric system

\begin{tabular}{llll}
\hline Configuration & $\begin{array}{l}\text { Energy Production } \\
\text { (kWh/year) }\end{array}$ & $\begin{array}{l}\text { Energy Consumption } \\
(\mathrm{kWh} / \mathrm{year})\end{array}$ & $\begin{array}{l}\text { Excess Energy } \\
(\mathrm{kWh} / \mathrm{year})\end{array}$ \\
\hline PV-WT-DG-battery & 5.103 .072 & 4.136 .751 & 847.231 \\
PV-DG-battery & 5.100 .836 & 4.136 .735 & 844.944 \\
PV-WT-battery & 5.099 .094 & 4.136 .728 & 843.106 \\
PV-battery & 5.096 .520 & 4.136 .734 & 840.486 \\
\hline
\end{tabular}

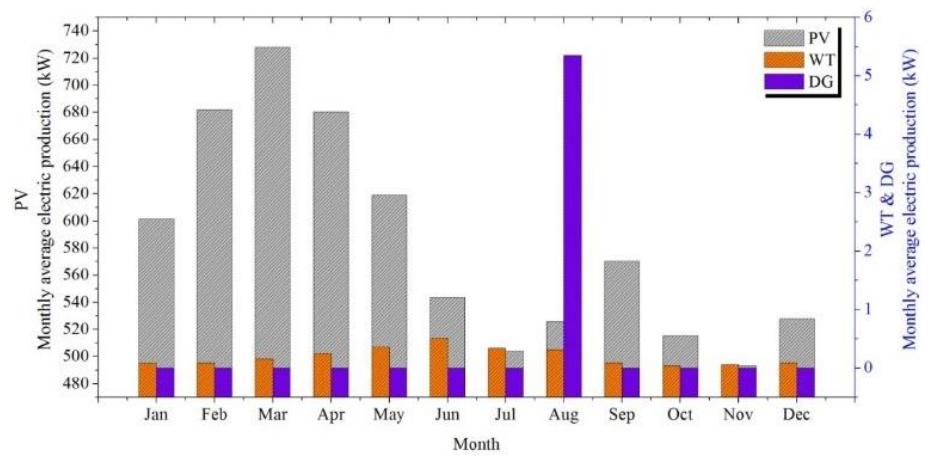

Figure 12. Monthly average electric production in the PV-WT-DG-battery system 


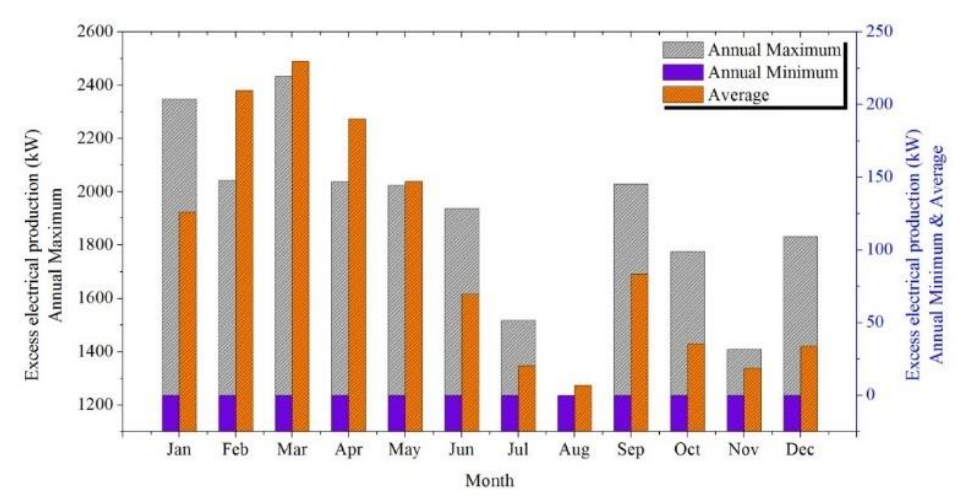

Figure 13. Monthly average excess electric energy in the PV-WT-DG-battery system

\subsection{Environmental analysis of the hybrid system}

From the design simulated by HOMER Pro, the hybrid PV-WT-DG-battery system has the more carbon dioxide emission of $2.692 \mathrm{~kg} /$ year, followed by hybrid PV-DG-Battery setup with $\mathrm{CO}_{2}$ of $2.355 \mathrm{~kg} / \mathrm{year}$. The PV-WT-battery and PV-battery arrangements have zero greenhouse gas emission due to the 100\% renewable fraction of the system. This shows that the hybrid PV-WT-battery and PV-battery systems are the most environmentally friendly configurations with zero emission, but unfortunately not economically viable because they have the highest NPC and COE compared to the optimum configuration system. It shows the hybrid PV-WT-battery and PV-battery systems are the most environmentally friendly setups with zero emission, but not economically feasible due to higher value of NPC and COE compared to the other optimal design. The hybrid system with the optimal design dependent on the less NPC and COE is still environmentally friendly due to less amount of greenhouse gas emission with $99.9 \%$ of energy generated from renewable sources compared other setup. Table 10 represents the greenhouse gas emission of the various configurations simulated by HOMER Pro.

Table 10. Comparison of GHG emission in hybrid electric system

\begin{tabular}{lllll}
\hline Quantity & $\begin{array}{l}\text { PV-WT-DG-battery } \\
\text { (kg/year) }\end{array}$ & $\begin{array}{l}\text { PV-DG-battery } \\
\text { (kg/year) }\end{array}$ & $\begin{array}{l}\text { PV-WT-battery } \\
\text { (kg/year) }\end{array}$ & $\begin{array}{l}\text { PV-battery } \\
(\mathrm{kg} / \text { year })\end{array}$ \\
\hline Carbon Dioxide & 2.692 & 2.355 & 0 & 0 \\
Carbon Monoxide & 13.9 & 12.2 & 0 & 0 \\
Unburned Hydrocarbon & 0.739 & 0.647 & 0 & 0 \\
Particulate Matter & 0.119 & 0.104 & 0 & 0 \\
Sulfur Dioxide & 6.58 & 5.76 & 0 & 0 \\
Nitrogen Oxides & 2.67 & 2.33 & 0 & 0 \\
\hline
\end{tabular}

\subsection{Sensitivity analysis of the hybrid electric system}

Certain sensitivity factors were providing into HOMER Pro software to decide the optimal system arrangement and corresponding techno-economic assessments for such system. By performing the sensitivity assessment for this hybrid system, a different value of yearly average solar radiation, average temperature, oscillation in average WS, rise and fall of the fuel price and changing the multiplication value of the capital cost, $\mathrm{RC}$ and $\mathrm{O} \& \mathrm{M}$ cost of the photovoltaic and wind system were conducted.

\subsubsection{Sensitivity analysis with the variation of average $S R$}

When the hybrid PV-WT-DG-battery system model in HOMER Pro, the yearly average solar radiation ranges from $4.5 \mathrm{kWh} / \mathrm{m}^{2} /$ day to $5.5 \mathrm{kWh} / \mathrm{m}^{2} /$ day. As saw in Table 11 , with the other design factors of the system are undisturbed, during the system is operating at yearly average SR was $4.5 \mathrm{kWh} / \mathrm{m}^{2} / \mathrm{day}$, optimum size of the photovoltaic and wind turbine required were setup $3500 \mathrm{~kW}$ and $406 \mathrm{~kW}$, which are $20 \mathrm{~kW}$ photovoltaic and $403 \mathrm{~kW}$ wind turbine more than when the system is operating at yearly average SR was $5.5 \mathrm{kWh} / \mathrm{m} 2 /$ day. Therefore, the capital cost, operating cost, NPC and COE was rises by around $62.2 \%$, $38.37 \%, 53.46 \%$, and $53.44 \%$ correspondingly as compared with the system is operating at average SR was $5.5 \mathrm{kWh} / \mathrm{m}^{2} /$ day appeared in Figure 14. 
Table 11. Sensitivity analysis results for hybrid electric system

\begin{tabular}{|c|c|c|c|c|c|c|c|c|c|c|c|c|}
\hline $\begin{array}{l}\text { Sensitivity } \\
\text { Variables }\end{array}$ & $\begin{array}{l}\text { Configuratio } \\
\mathrm{n}\end{array}$ & $\begin{array}{l}\text { PV } \\
(\mathrm{kW})\end{array}$ & $\begin{array}{l}\text { WT } \\
(\mathrm{kW} \\
)\end{array}$ & $\begin{array}{l}\text { DG } \\
(\mathrm{kW} \\
)\end{array}$ & $\begin{array}{l}\text { Batter } \\
\mathrm{y}\end{array}$ & $\begin{array}{l}\text { Converte } \\
\mathrm{r}(\mathrm{kW})\end{array}$ & NPC (\$) & $\begin{array}{l}\mathrm{COE} \\
(\$ / \mathrm{kWh} \\
)\end{array}$ & $\begin{array}{l}\text { Initial } \\
(\$)\end{array}$ & $\begin{array}{l}\text { Operating } \\
\text { Cost } \\
\text { (\$/year) }\end{array}$ & $\begin{array}{l}\mathrm{RF} \\
(\%)\end{array}$ & $\begin{array}{l}\text { Total } \\
\text { Fuel } \\
\text { (L/year } \\
\text { ) }\end{array}$ \\
\hline \multicolumn{13}{|c|}{ Solar radiation variation at Fuel cost of $0.86 \$ / \mathrm{L}$, Temperature of $27.07^{\circ} \mathrm{C}$, Wind speed of $3.29 \mathrm{~m} / \mathrm{s}$} \\
\hline $\begin{array}{l}4.5 \\
\mathrm{kWh} / \mathrm{m}^{2} / \mathrm{da} \\
\mathrm{y}\end{array}$ & $\begin{array}{l}\text { PV-WT- } \\
\text { DG-battery }\end{array}$ & 3500 & 406 & 500 & 1577 & 1851 & 56.051 .220 & 0.2452 & 35.481 .570 .27 & 372.154 .20 & 99.8 & 1.997 \\
\hline $\begin{array}{l}4.8 \\
\mathrm{kWh} / \mathrm{m}^{2} / \mathrm{da} \\
\mathrm{y}\end{array}$ & $\begin{array}{l}\text { PV-WT- } \\
\text { DG-battery }\end{array}$ & 3497 & 1 & 500 & 1773 & 1807 & 36.428 .900 & 0.1593 & 18.653.257.57 & 321.603 .90 & 99.9 & 709 \\
\hline $\begin{array}{l}5.5 \\
\mathrm{kWh} / \mathrm{m}^{2} / \mathrm{da} \\
\mathrm{y}\end{array}$ & $\begin{array}{l}\text { PV-WT- } \\
\text { DG-battery }\end{array}$ & 3480 & 3 & 500 & 1035 & 1838 & 26.089.320 & 0.1141 & 13.411.010.17 & 229.381 .00 & 99.9 & 769 \\
\hline \multicolumn{13}{|c|}{ Temperature variation at Fuel cost of $0.86 \$ / \mathrm{L}$, Solar radiation of $5.14 \mathrm{kWh} / \mathrm{m}^{2} /$ day, Wind speed of $3.29 \mathrm{~m} / \mathrm{s}$} \\
\hline $20{ }^{\circ} \mathrm{C}$ & $\begin{array}{l}\text { PV-WT- } \\
\text { DG-battery }\end{array}$ & 3500 & 1 & 500 & 1068 & 2069 & 26.754 .730 & 0.1170 & 13.639 .721 .07 & 237.281 .90 & 99.9 & 1.156 \\
\hline $35^{\circ} \mathrm{C}$ & $\begin{array}{l}\text { PV-WT- } \\
\text { DG-battery }\end{array}$ & 3482 & 5 & 500 & 1412 & 1867 & 31.594 .280 & 0.1382 & 16.224 .751 .56 & 278.071 .60 & 99.9 & 1.283 \\
\hline $45^{\circ} \mathrm{C}$ & $\begin{array}{l}\text { PV-WT- } \\
\text { DG-battery }\end{array}$ & 3500 & 145 & 500 & 1359 & 3528 & 40.241 .830 & 0.1760 & 22.535 .976 .91 & 320.341 .30 & 99.9 & 1.489 \\
\hline \multicolumn{13}{|c|}{ Wind speed variation at Fuel cost of $0.86 \$ / \mathrm{L}$, Temperature $27.07{ }^{\circ} \mathrm{C}$, Solar radiation of $5.14 \mathrm{kWh} / \mathrm{m}^{2} /$ day } \\
\hline $2.5 \mathrm{~m} / \mathrm{s}$ & $\begin{array}{l}\text { PV-WT- } \\
\text { DG-battery }\end{array}$ & 3500 & 3 & 500 & 1.212 & 1.964 & 28.797 .300 & 0.1259 & 14.743 .465 .43 & 254.267 .60 & 99.9 & 1.156 \\
\hline $4 \mathrm{~m} / \mathrm{s}$ & $\begin{array}{l}\text { PV-WT- } \\
\text { DG-battery }\end{array}$ & 3500 & 1 & 500 & 1.222 & 2.090 & 28.944 .800 & 0.1266 & 14.753 .120 .52 & 256.761 .50 & 99.9 & 1.026 \\
\hline $5 \mathrm{~m} / \mathrm{s}$ & $\begin{array}{l}\text { PV-WT- } \\
\text { DG-battery }\end{array}$ & 3500 & 43 & 500 & 906 & 1801 & 26.508 .510 & 0.1159 & 14.304 .391 .87 & 220.801 .70 & 99.9 & 1.150 \\
\hline \multicolumn{13}{|c|}{ Fuel cost variation at Solar radiation of $5.14 \mathrm{kWh} / \mathrm{m}^{2} /$ day, Temperature of $27.07{ }^{\circ} \mathrm{C}$, Wind speed of $3.29 \mathrm{~m} / \mathrm{s}$} \\
\hline $0.5 \$ / \mathrm{L}$ & $\begin{array}{l}\text { PV-WT- } \\
\text { DG-battery }\end{array}$ & 3500 & 1 & 500 & 1.222 & 2090 & 28.924 .370 & 0.1265 & 14.753.114.69 & 256.391 .90 & 99.9 & 1027 \\
\hline $1.0 \$ / \mathrm{L}$ & $\begin{array}{l}\text { PV-WT- } \\
\text { DG-battery }\end{array}$ & 3500 & 1 & 500 & 1.222 & 2090 & 28.952 .740 & 0.1266 & 14.753 .114 .69 & 256.905 .20 & 99.9 & 1027 \\
\hline $1.5 \$ / L$ & $\begin{array}{l}\text { PV-WT- } \\
\text { DG-battery }\end{array}$ & 3500 & 1 & 500 & 1.222 & 2.090 & 28.981 .110 & 0.1268 & 14.753 .114 .69 & 257.418 .60 & 99.9 & 1027 \\
\hline \multicolumn{13}{|c|}{$\begin{array}{c}\text { Solar PV capital, Replacement and O\&M cost multiplier variations at Solar radiation of } 5.14 \mathrm{kWh} / \mathrm{m}^{2} / \text { day, Fuel cost of } 0.86 \$ / \mathrm{L} \text {, } \\
\text { Temperature of } 27.07{ }^{\circ} \mathrm{C} \text {, Wind speed of } 3.29 \mathrm{~m} / \mathrm{s}\end{array}$} \\
\hline $0.6 \%$ & $\begin{array}{l}\text { PV-WT- } \\
\text { DG-battery }\end{array}$ & 3500 & 1 & 500 & 1.222 & 2.090 & 24.910 .280 & 0.1089 & 12.653 .114 .69 & 221.761 .50 & 99.9 & 1.027 \\
\hline $1.4 \%$ & $\begin{array}{l}\text { PV-WT- } \\
\text { DG-battery }\end{array}$ & 3500 & 1 & 500 & 1.222 & 2.090 & 32.979 .310 & 0.1442 & 16.853 .114 .69 & 291.761 .50 & 99.9 & 1.027 \\
\hline \multicolumn{13}{|c|}{$\begin{array}{l}\text { WT capital, Replacement and O\&M cost multiplier variations at Solar radiation of } 5.14 \mathrm{kWh} / \mathrm{m}^{2} / \text { day, Fuel cost of } 0.86 \$ / \mathrm{L} \text {, Temperature } \\
\text { of } 27.07^{\circ} \mathrm{C} \text {, Wind speed of } 3.29 \mathrm{~m} / \mathrm{s}\end{array}$} \\
\hline $0.6 \%$ & $\begin{array}{l}\text { PV-WT- } \\
\text { DG-battery }\end{array}$ & $\begin{array}{l}350 \\
0\end{array}$ & 1 & 500 & 1.215 & 2.007 & $\begin{array}{l}28.750 .59 \\
0\end{array}$ & 0.1257 & $\begin{array}{l}14.666 .621 .7 \\
4\end{array}$ & $\begin{array}{l}254.712 .8 \\
0\end{array}$ & $\begin{array}{l}99 . \\
9\end{array}$ & 1.156 \\
\hline $1.4 \%$ & $\begin{array}{l}\text { PV-WT- } \\
\text { DG-battery }\end{array}$ & $\begin{array}{l}350 \\
0\end{array}$ & 1 & 500 & 1.222 & 2.090 & $\begin{array}{l}28.966 .78 \\
0\end{array}$ & 0.1267 & $\begin{array}{l}14.771 .114 .6 \\
9\end{array}$ & $\begin{array}{l}256.833 .5 \\
0\end{array}$ & $\begin{array}{l}99 . \\
9\end{array}$ & 1.027 \\
\hline
\end{tabular}

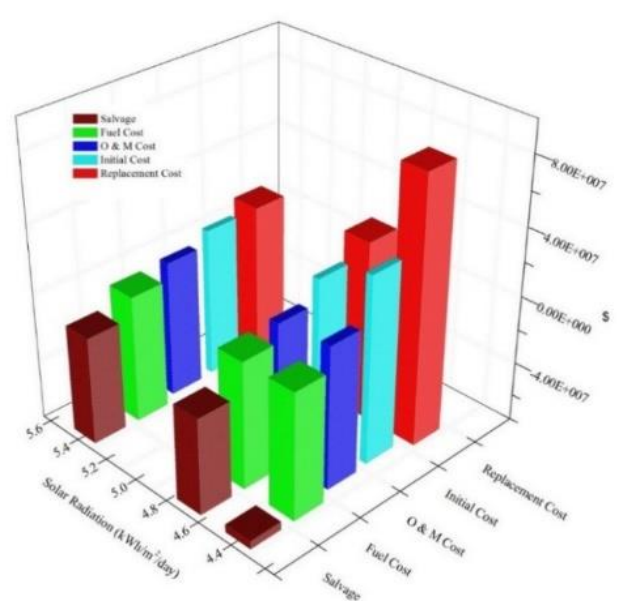

Figure 14. Cash flow summary of PV-WT-DG-battery system at different solar radiation 


\subsubsection{Sensitivity analysis with the variation of average temperature}

By keeping the yearly average solar radiation, wind speed and other design factors are constant for this optimal hybrid system, the yearly average temperature were ranges from $20{ }^{\circ} \mathrm{C}$ to $45{ }^{\circ} \mathrm{C}$. When the hybrid system is operating at average temperature was $20{ }^{\circ} \mathrm{C}$, the quantity of the photovoltaic and wind turbine required were setup $3500 \mathrm{~kW}$ and $1 \mathrm{~kW}$, the wind turbine quantity is $403 \mathrm{~kW}$ less than when the system is operating at yearly average temperature were $45^{\circ} \mathrm{C}$ as shown in Table 11 . Accordingly, the capital cost, operating cost, NPC and COE was drops by almost $39.48 \%, 25.93 \%, 33.51 \%$ and $33.52 \%$ in that order as related to when the system is operating at temperature was $45^{\circ} \mathrm{C}$ as displayed in Figure 15 .

\subsubsection{Sensitivity analysis with the variation of average wind speed}

The average WS of the WT changes between $2.5-5 \mathrm{~m} / \mathrm{s}$ with fuel cost of $0.86 \mathrm{~S} / \mathrm{L}$, Temperature $27.07{ }^{\circ} \mathrm{C}$, Solar radiation of $5.14 \mathrm{kWh} / \mathrm{m}^{2} /$ day. As observed in Table 11 when the system is operate at average WS was $2.5 \mathrm{~m} / \mathrm{s}$, the size of PV and WT wanted were found to be $3500 \mathrm{~kW}$ and $3 \mathrm{~kW}$, the size of the WT is $40 \mathrm{~kW}$ greater than when the system is operates average WS was $5 \mathrm{~m} / \mathrm{s}$. Therefore, the capital cost, operating cost, NPC and COE was rises by roughly $2.99 \%, 13.16 \%, 7.95 \%$ and $7.94 \%$ respectively as associated to when the average WS was $5 \mathrm{~m} / \mathrm{s}$ as presented in Figure 16.

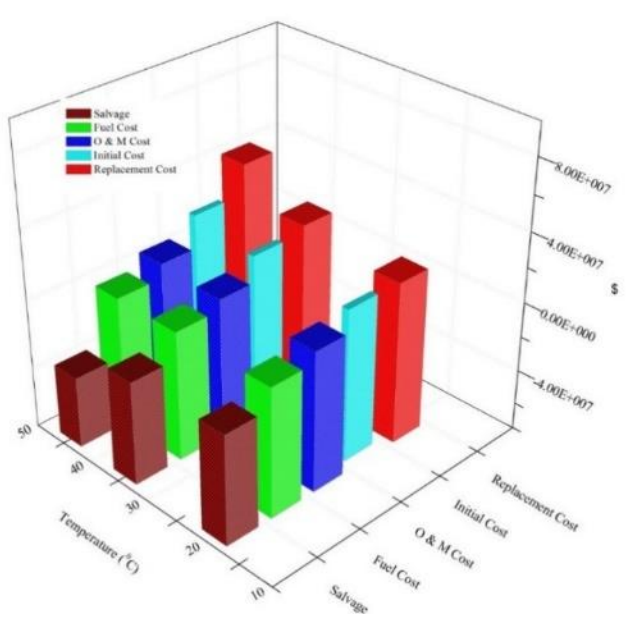

Figure 15. Cash flow summary of PV-WT-DGbattery system at different temperatures

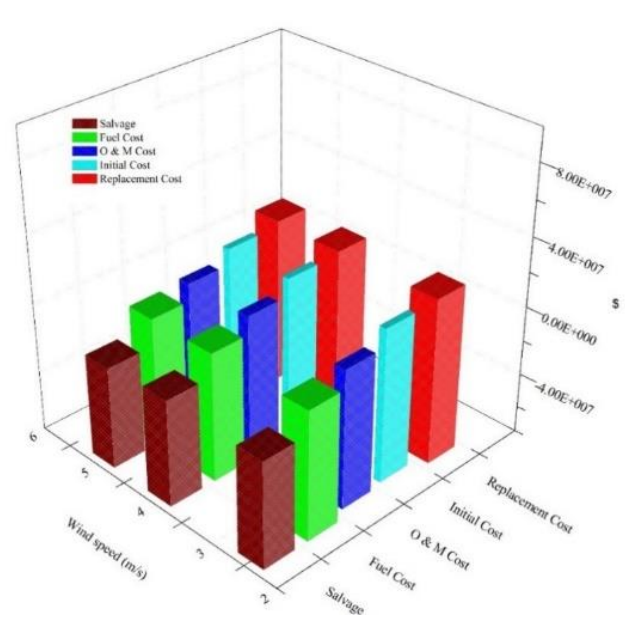

Figure 16. Cash flow summary of PV-WT-DGbattery system at different wind speed

\subsubsection{Sensitivity analysis with the variation of fuel price}

The universal oil and gas area encounters changes in the costs of prepared raw petroleum items, among the few reasons for these value fluctuations are governmental strategies and complexities emerging from the extraction and handling of unrefined petroleum into items, for example, diesel fuel. Therefore, a sensitivity assessment of variation in diesel prices comes to be essential.

Here, when the cost of fuel were differed between $\$ 0.5 / \mathrm{L}, \$ 1.0 / \mathrm{L}$ and $\$ 1.5 / \mathrm{L}$ at $\mathrm{SR}$ of $5.14 \mathrm{kWh} / \mathrm{m}^{2} /$ day, Temperature of $27.07{ }^{\circ} \mathrm{C}$, WS of $3.29 \mathrm{~m} / \mathrm{s}$, it was seen that costs of diesel impacted the total NPC and COE as found in Table 11. NPC observed at $\$ 0.5 / \mathrm{L}, \$ 1.0 / \mathrm{L}$ and $\$ 1.5 / \mathrm{L}$ expanded in extent by $0.098 \%, 0.099 \%$ and $0.12 \%$ in that order. The cost of energy saw at $\$ 0.5 / \mathrm{L}, \$ 1.0 / \mathrm{L}$ and $\$ 1.5 / \mathrm{L}$ expanded by $0.078 \%, 0.15 \%$, and $0.24 \%$ correspondingly.

\subsubsection{Sensitivity analysis with variations of $P V$ and WT capital, $R C$ and $O \& M$ costs}

In this assessment, the photovoltaic and wind system initial cost, $\mathrm{RC}$ and O\&M costs were given for the period of hybrid system model in HOMER Pro, hereafter an adjustment in the initial, replacement and O $\& \mathrm{M}$ costs. At an yearly average SR of $5.14 \mathrm{kWh} / \mathrm{m}^{2} /$ day, fuel cost of $0.86 \$ / \mathrm{L}$, average temperature of $27.07{ }^{\circ} \mathrm{C}$, average WS of $3.29 \mathrm{~m} / \mathrm{s}$, varying the initial cost, replacement cost, operation and $\mathrm{O} \& \mathrm{M}$ costs of the photovoltaic and WT was multiplied by $0.6 \%$ and $1.4 \%$ of the original cost. During the photovoltaic system costs are multiplied by $0.6 \%$ and $1.4 \%$, the net present cost vary from $\$ 24,910,280$ to $\$ 32,979,310$ and COE from $0.1089 \$ / \mathrm{kWh}$ to $0.1442 \$ / \mathrm{kWh}$ as presented in Table 11 . When the wind turbine costs are multiplied by $0.6 \%$ and $1.4 \%$, the net present cost vary from $\$ 28,750,590$ to $\$ 28,966,780$ and COE from $0.1257 \$ / \mathrm{kWh}$ to $0.1267 \$ / \mathrm{kWh}$ as presented in Table 11 . 


\subsubsection{Sensitivity analysis with variations of fuel price and average solar radiation}

For this assessment, the average solar radiation and fuel cost considered for sensitivity analysis ignoring the wind speed. The solar radiation and fuel costs were both fluctuated to get the impact of variation on the hybrid system economy. In spite of the fact that the diesel cost is selected at $\$ 0.86 / \mathrm{L}$, it ranges between $\$ 0.5 / \mathrm{L}-\$ 1.5 / \mathrm{L}$ and the average solar radiation as well fluctuates between 4.5 and $5.5 \mathrm{~kW} / \mathrm{m}^{2} / \mathrm{day}$. Table 12 shows observed sensitivity results, due to the fuel cost and solar radiation fluctuations with corresponding NPC and COE. When solar radiation is increases and fuel cost decreases the system NPC and COE are decreases. Whereas a decrease the solar radiation and increases the fuel cost the system NPC and COE are increases. Figure 17 and Figure 18 exposed the total fuel cost per year and COE respectively for the hybrid PV-WT-DG-battery system.

Table 12. Sensitivity analysis results for optimal hybrid PV-WT-DG-battery system

\begin{tabular}{llllllllllll}
\hline $\begin{array}{l}\text { Fuel } \\
\begin{array}{l}\text { Cost } \\
(\$ / \mathrm{L})\end{array}\end{array}$ & $\begin{array}{l}\text { Solar } \\
\text { Radiation } \\
\left(\mathrm{kWh} / \mathrm{m}^{2} / \text { day }\right)\end{array}$ & $\begin{array}{l}\mathrm{PV} \\
(\mathrm{kW})\end{array}$ & $\begin{array}{l}\text { WT } \\
(\mathrm{kW})\end{array}$ & $\begin{array}{l}\text { DG } \\
(\mathrm{kW})\end{array}$ & Battery & $\begin{array}{l}\text { Converter } \\
(\mathrm{kW})\end{array}$ & DS & NPC $(\$)$ & $\begin{array}{l}\mathrm{COE} \\
(\$ / \mathrm{kWh})\end{array}$ & $\begin{array}{l}\text { Initial } \\
(\$)\end{array}$ & $\begin{array}{l}\mathrm{Cost}^{2} \\
\mathrm{CO}_{2} \\
\mathrm{emissi} \\
\text { on }\end{array}$ \\
\hline 0.5 & 4.5 & 3500 & 452 & 500 & 1.477 & 1.911 & LF & 57.178 .810 & 0.2501 & 36.844 .784 .40 & 4.967 \\
0.5 & 4.8 & 3497 & 1 & 500 & 1.773 & 1.807 & LF & 36.414 .790 & 0.1592 & 18.653 .257 .57 & 1.860 \\
0.5 & 5.5 & 3480 & 3 & 500 & 1.035 & 1.838 & LF & 26.074 .030 & 0.1140 & 13.411 .010 .17 & 2.016 \\
1 & 4.5 & 3500 & 452 & 500 & 1.477 & 1.911 & LF & 57.231 .150 & 0.2503 & 36.844 .784 .40 & 4.967 \\
1 & 4.8 & 3497 & 1 & 500 & 1.773 & 1.807 & LF & 36.434 .390 & 0.1593 & 18.653 .257 .57 & 1.860 \\
1 & 5.5 & 3480 & 3 & 500 & 1.035 & 1.838 & LF & 26.095 .270 & 0.1141 & 13.411 .010 .17 & 2.016 \\
1.5 & 4.5 & 3500 & 452 & 500 & 1.477 & 1.911 & LF & 57.283 .490 & 0.2506 & 36.844 .784 .4 & 4.967 \\
1.5 & 4.8 & 3497 & 1 & 500 & 1.773 & 1.807 & LF & 36.453 .990 & 0.1594 & 18.653 .257 .57 & 1.860 \\
1.5 & 5.5 & 3480 & 3 & 500 & 1.035 & 1.838 & LF & 26.116 .520 & 0.1142 & 13.411 .010 .17 & 2.016 \\
\hline
\end{tabular}

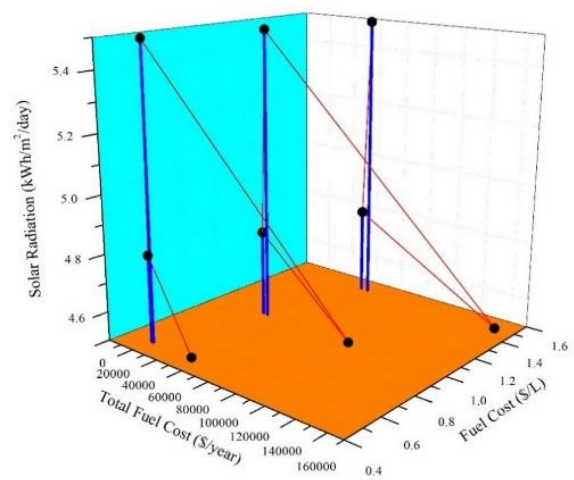

Figure 17. Effect of solar radiation $\left(\mathrm{kWh} / \mathrm{m}^{2} /\right.$ day $)$ and fuel price $(\$ / \mathrm{L})$ on the total fuel price $(\$ /$ year) of the optimal configuration system

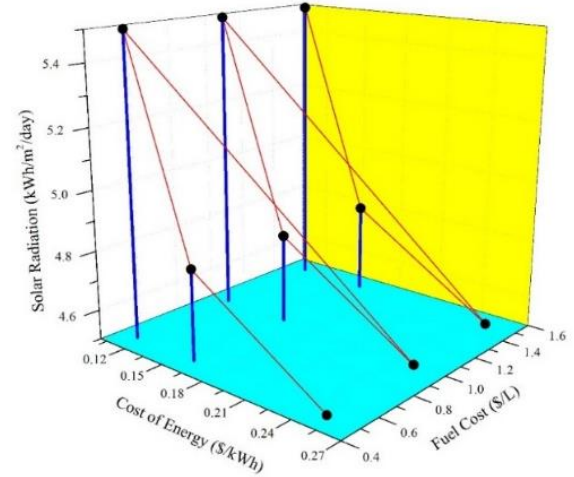

Figure 18. Effect of solar radiation $\left(\mathrm{kWh} / \mathrm{m}^{2} /\right.$ day $)$ and fuel price $(\$ / \mathrm{L})$ on the $\mathrm{COE}$ of the optimal configuration system

\section{CONCLUSION}

In this assessment, a gird isolated hybrid solar photovoltaic/wind turbine/diesel generator/battery system for electricity generation for Arunai Engineering College in Tiruvannamalai, Tamil Nadu, Southern India. The HOMER Pro software is used to design a hybrid electric system. The proposed system simulation results were determined based on the minimum NPC and COE. In this system were found the four categorized optimal design configuration which take account of PV-WT-DG-battery, PV-DG-battery, PVWT-battery and PV-battery systems. The acquired results from this hybrid system, it very well be determined that the combination of the energy sources with less NPC of $\$ 28.944 .800$ and COE of $\$ 0.1266$ is the PVWT-DG-battery and is the optimal combination for all the sensitivity results. a) The optimal PV-WT-DGbattery combination of the system has a renewable fraction of $99.9 \%$ with delivered yearly greenhouse gas emission of $2.692 \mathrm{~kg}$; b) The fourth optimal PV-battery combination of the system has a zero-greenhouse gas emission due to the $100 \%$ renewable fraction. Unfortunately, the combination has the highest NPC of $\$ 30.601 .110$ and COE of $\$ 0.1338$ because of the huge amount of costs need to spend for converter and storage batteries; c) The economic and environmental analysis has demonstrated that the optimal PV-WTDG-battery combination system is economically and environmentally feasible for the reason that of less capital cost, operating cost, NPC and COE with less amount of greenhouse gas emission for electric power

Techno-economic environmental assessment of hybrid renewable energy system in ... (Venkatachalam $K \mathrm{M}$ ) 
generation in Arunai Engineering College in southern India; d) For the sensitivity variables, which are average $\mathrm{SR}$, average temperature, average WS, fuel price, multiplication factor of capital cost, RC and O \& M cost of the photovoltaic and wind system. It can be found that with a higher value of average SR, average WS with lower value of multiplication factor, fuel price and temperature, the NPC and COE decreases. Due to the higher value of multiplication factor, fuel price and temperature with lower value of SR and WS, the NPC and COE increases; and e) In this techno-economic research of harnessing RE generation for institutional and rural area electrification purpose can be functional to developing countries.

\section{ACKNOWLEDGMENT}

This work was supported by Wind Energy Division, Ministry of New \& Renewable Energy, Government of India under grant (IFD Dy. No. 1429 dated 04/11/2016, Demand No. 61/69, Budget Head: 2810.00.104.04.05.31/35).

\section{REFERENCES}

[1] J. Kumar, B.V. Suryakiran, A. Verma and T. S. Bhatti, "Analysis of techno-economic viability with demand response strategy of a grid-connected microgrid model for enhanced rural electrification in Uttar Pradesh state, India," Energy, vol. 178, pp. 176-185, 2019, doi: 10.1016/j.energy.2019.04.105.

[2] K. P. Satsangi, D. B. Das, G.S. S. Babu, and A.K. Saxena, "Performance analysis of grid interactive solar photovoltaic plant in India," Energy for Sustainable Development, vol. 47, pp. 9-16, 2018, doi: 10.1016/j.esd.2018.08.003.

[3] R. Sharma and S. Goel, "Performance analysis of a 11.2 kWp roof top grid-connected PV system in Eastern Indi," Energy Reports, vol. 3, pp. 76-84, 2017, doi: 10.1016/j.egyr.2017.05.001.

[4] S. Bhakta and V. Mukherjee, "Solar potential assessment and performance indices analysis of photovoltaic generator for isolated Lakshadweep Island of India," Sustainable Energy Technologies and Assessments, vol. 17, pp. 1-10, 2016, doi: 10.1016/j.seta.2016.07.002.

[5] S. K. Yadav and U. Bajpai, "Performance evaluation of a rooftop solar photovoltaic power plant in Northern India," Energy for Sustainable Development, vol. 43, pp. 130-138, 2018, doi: 10.1016/j.esd.2018.01.006.

[6] S. Sundaram and J. S. C. Babu, "Performance evaluation and validation of $5 \mathrm{MWp}$ grid connected solar photovoltaic plant in South India," Energy Conversion and Management, vol. 100, pp. 429-439, 2015, doi: 10.1016/j.enconman.2015.04.069.

[7] B. Dobaria, M. Pandya and M. Aware, "Analytical assessment of $5.05 \mathrm{kWp}$ grid tied photovoltaic plant performance on the system level in a composite climate of western India," Energy, vol. 111, pp. 47-51, 2016, doi: 10.1016/j.energy.2016.05.082.

[8] S. H. Kulkarni, T. R. Anil and R. D. Gowdar, "Wind Energy Development in India and a Methodology for Evaluating Performance of Wind Farm Clusters, " Journal of Renewable Energy, vol. 2016, p. 6769405, 2016, doi: $10.1155 / 2016 / 6769405$.

[9] M. M. R. Singaravel and S. A. Daniel, "MPPT With Single DC-DC Converter and Inverter for Grid-Connected Hybrid Wind-Driven PMSG-PV System," in IEEE Transactions on Industrial Electronics, vol. 62, no. 8, pp. 48494857, Aug. 2015, doi: 10.1109/TIE.2015.2399277.

[10] Miloud Benmedjahed, Rachid Maouedj, Samir Mouhadjer, "Wind energy resource assessment of desert sites in Algeria: energy and reduction of $\mathrm{CO} 2$ emissions," International Journal ofApplied Power Engineering (IJAPE), vol. 9, no. 1, pp. 22-28, 2020, doi: 10.11591/ijape.v9.i1.pp22-28.

[11] A. Chauhan, R. P. Saini, "Techno-economic feasibility study on Integrated Renewable Energy System for an isolated community of India, " Renewable and Sustainable Energy Reviews, vol. 59, pp. 388-405, 2016, doi: 10.1016/j.rser.2015.12.290.

[12] A. Chauhan, R. P. Saini, "Techno-economic optimization based approach for energy management of a stand-alone integrated renewable energy system for remote areas of India," Energy, vol. 94, pp. 138-156, 2016, doi: 10.1016/j.energy.2015.10.136.

[13] W. M. Amutha and V. Rajini, "Cost benefit and technical analysis of rural electrification alternatives in southern India using HOMER," Renewable and Sustainable Energy Reviews, vol. 62, pp. 236-246, 2016, doi: 10.1016/j.rser.2016.04.042.

[14] M. J. Khan, A. K. Yadav and L. Mathew, "Techno economic feasibility analysis of different combinations of PVWind- Diesel-Battery hybrid system for telecommunication applications in different cities of Punjab, India," Renewable and Sustainable Energy Reviews, vol. 76, pp. 577-607, 2017, doi: 10.1016/j.rser.2017.03.076.

[15] M. Jahangiri at al., "Techno-econo-environmental optimal operation of grid-wind-solar electricity generation with hydrogen storage system for domestic scale, case study in Chad," International journal of hydrogen energy, vol. 44, pp. 28613-28628, 2019, doi: 10.1016/j.ijhydene.2019.09.130.

[16] C. Ghenai and M. Bettayeb, "Modelling and performance analysis of a stand-alone hybrid solar PV/Fuel Cell/Diesel Generator power system for university building," Energy, vol. 171, pp. 180-189, 2019, doi: 10.1016/j.energy.2019.01.019. 
[17] F. Khalid, I. Dincer and Marc A. Rosen, "Techno-economic assessment of a renewable energy based integrated multi generation system for green buildings," Applied Thermal Engineering, vol. 99, pp. 1286-1294, 2016, doi: 10.1016/j.applthermaleng.2016.01.055.

[18] A. Yasin and M. Alsayed, "Optimization with excess electricity management of a PV, energy storage and diesel generatorhybrid system using HOMER Pro software," International Journal ofApplied Power Engineering (IJAPE), vol. 9, vol. 3, pp. 267-283, 2020, doi: 10.11591/ijape.v9.i3.pp267-283.

[19] S. Salisu, M. W. Mustafa, L. Olatomiwa and O. O. Mohammed, "Assessment of technical and economic feasibility for a hybrid PV-wind-diesel-battery energy system in a remote community of north central Nigeria," Alexandria Engineering Journal, vol. 58, no. 4, pp. 1103-1118, 2019, doi: 10.1016/j.aej.2019.09.013.

[20] M. Usman, M. T. Khan, A. S. Rana and S. Ali, "Techno-economic analysis of hybrid solar-diesel-grid connected power generation system," Journal of Electrical Systems and Information Technology, vol. 5, no. 3, pp. 653662,2018, doi: 10.1016/j.jesit.2017.06.002.

[21] F. C. Amanze and D. J. Amanze, "Off-grid rural electrification using integrated renewable energy sources," International Journal of Advances in Applied Sciences (IJAAS), vol. 10, no. 1, pp. 1-12, 2021, doi: 10.11591/ijaas.v10.i1.pp1-12.

[22] M. Hossain, S. Mekhilef, L. Olatimiwa, "Performance evaluation of a stand-alone PV-wind-diesel-battery hybrid system feasible for a large resort center in South China Sea, Malaysia," Sustainable Cities and Society, vol. 28, pp. 358-366, 2017, doi: 10.1016/j.scs.2016.10.008.

[23] M. Nurunnabi, N. K. Roy, E. Hossain and H. R. Pota, "Size Optimization and Sensitivity Analysis of Hybrid Wind/PV Micro-Grids- A Case Study for Bangladesh," in IEEE Access, vol. 7, pp. 150120-150140, 2019, doi: 10.1109/ACCESS.2019.2945937.

[24] M. R. Elkadeem, S. Wang, A. M. Azmy, E. G. Atiya, Z. Ullah and S. W. Sharshir, "A systematic approach for planning and design of hybrid renewable energy-based microgrid with techno-economic optimization: A case study on an urban community in Egypt," Sustainable Cites and Society, vol. 54, p. 102013, 2020, doi: 10.1016/j.scs.2019.102013.

[25] T. M. Azerefegn, R. Bhandari and A. V. Ramayya, "Techno-economic analysis of grid-integrated PV/wind systems for electricity reliability enhancement in Ethiopian industrial park," Sustainable Cites and Society, vol. 53, p. 101915, 2020, doi: 10.1016/j.scs.2019.101915.

[26] L. Lozano, E. M. Querikiol, M. L. S. Abundo and L. M. Bellotindos, "Techno-economic analysis of a cost-effective power generation system for off-grid island communities: A case study of Gilutongan Island, Cordova, Cebu, Philippines," Renewable Energy, vol. 140, pp. 905-911, 2019, doi: 10.1016/j.renene.2019.03.124.

[27] S. Bhakta and V. Mukherjee, "Performance indices evaluation and techno economic analysis of photovoltaic power plant for the application of isolated India's island," Sustainable Energy Technologies and Assessments, vol. 20, pp. 9-24, 2017, doi: 10.1016/j.seta.2017.02.002.

[28] A. Singh, P. Baredar and B. Gupta, "Techno-economic feasibility analysis of hydrogen fuel cell and solar photovoltaic hybrid renewable energy system for academic research building," Energy Conversion and Management, vol. 145, pp. 398-414, 2017, doi: 10.1016/j.enconman.2017.05.014.

[29] J. Ahmad, et al., "Techno economic analysis of a wind-photovoltaic-biomass hybrid renewable energy system for rural electrification: A case study of Kallar Kahar," Energy, vol. 148, pp. 208-234, 2018, doi: 10.1016/j.energy.2018.01.133.

[30] M.A. Baseer, A. Alqahtani and S. Rehman, "Techno-economic design and evaluation of hybrid energy systems for residential communities: Case study of Jubail industrial city," Journal of Cleaner Production, vol. 237, p. 117806, 2019, doi: 10.1016/j.jclepro.2019.117806.

[31] A. S. K. Dalabeeh, "Techno-economic analysis of wind power generation for selected locations in Jordan," Renewable Energy, vol. 101, pp. 1369-1378, 2017, doi: 10.1016/j.renene.2016.10.003.

[32] W. Ma, J. Fan, S. Fang and G. Liu, "Techno-economic potential evaluation of small-scale grid-connected renewable power systems in China," Energy Conversion and Management, vol. 196, pp. 430-442, 2019, doi: 10.1016/j.enconman.2019.06.013.

[33] D. Thomas, O. Deblecker and C. S. Ioakimidis, "Optimal design and techno-economic analysis of an autonomous small isolated microgrid aiming at high RES penetration," Energy, vol. 116, pp. 364-379, 2016, doi: 10.1016/j.energy.2016.09.119.

[34] W. Ma, X. Xue, Gang Liu and R. Zhou, "Techno-economic evaluation of a community-based hybrid renewable energy system considering site-specific nature," Energy Conversion and Management, vol. 171, pp. 1737-1748, 2018, doi: 10.1016/j.enconman.2018.06.109.

[35] S. Al-Hamadani, "Solar energy as a potential contributor to help bridge the gap between electricity supply and growing demand in Iraq: A review," International Journal of Advances in Applied Sciences (IJAAS), vol. 9, no. 4, pp. 302-312, 2020, doi: 10.11591/ijaas.v9.i4.pp302-312.

[36] F. Fodhil, A. Hamidat and O. Nadjemi, "Potential, optimization and sensitivity analysis of photovoltaic-dieselbattery hybrid energy system for rural electrification in Algeria," Energy, vol. 169, pp. 613-624, 2019, doi: 10.1016/j.energy.2018.12.049.

[37] B. K. Das, N. Hoque, S. Mandal, T. K. Pal, M. A. Raihan, "A techno-economic feasibility of a stand-alone hybrid power generation for remote area application in Bangladesh," Energy, vol. 134, pp. 775-788, 2017, doi: 10.1016/j.energy.2017.06.024.

[38] A. C. Duman and Ö. Güler, "Techno-economic analysis of off-grid photovoltaic LED road lighting systems: A case study for northern, central and southern regions of Turkey," Building and Environment, 2019, vol. 156, pp. 89-98, doi: 10.1016/j.buildenv.2019.04.005.

Techno-economic environmental assessment of hybrid renewable energy system in ... (Venkatachalam K M) 
[39] C. Li, D. Zhou, H. Wang, H. Cheng and D. Li, "Feasibility assessment of a hybrid PV/diesel/battery power system for a housing estate in the severe cold zoned A case study of Harbin, China," Energy 2019, vol. 185, pp. 671-681, doi: 10.1016/j.energy.2019.07.079.

[40] M. R. Elkadeem, S. Wang, S. W. Sharshir and E. G. Atia, "Feasibility analysis and techno-economic design of gridisolated hybrid renewable energy system for electrification of agriculture and irrigation area: A case study in Dongola, Sudan," Energy Conversion and Management, vol. 196, pp. 1453-1478, 2019, doi: 10.1016/j.enconman.2019.06.085.

[41] C. Li and W. Yu, "Techno-economic comparative analysis of off-grid hybrid photovoltaic/diesel/battery and photovoltaic/battery power systems for a household in Urumqi, China," Journal of Cleaner Production, vol. 124, pp. 258-265, 2016, doi: 10.1016/j.jclepro.2016.03.002.

[42] M. S. Islam, "A Techno-Economic Feasibility Analysis of Hybrid Renewable Energy Supply Options for a GridConnected Large Office Building in Southeastern part of France," Sustainable Cities and Society, 2018, vol. 38, pp. 492-508, doi: 10.1016/j.scs.2018.01.022.

[43] M. K. Shahzad, A. Zahid, T. ur Rashid, M. A. Rehan, M. Ali and M. Ahmad, "Techno-economic feasibility analysis of a solar-biomass off grid system for the electrification of remote rural areas in Pakistan using HOMER software," Renewable Energy, vol. 106, pp. 264-273, 2017, doi: 10.1016/j.renene.2017.01.033.

[44] L. M. Halabi, S. Mekhilef, L. Olatomiwa and J. Hazelton, "Performance analysis of hybrid PV/diesel/battery system using HOMER: A case study Sabah, Malaysia," Energy Conversion and Management, vol. 144, pp. 322339, 2017, doi: 10.1016/j.enconman.2017.04.070.

[45] U. S. Kumar and P. S. Manoharan, "Economic analysis of hybrid power systems (PV/diesel) in different climatic zones of Tamil Nadu," Energy Conversion and Management, vol. 80, pp. 469-476, 2014, doi: 10.1016/j.enconman.2014.01.046.

[46] NASA, Surface Meteorology and Solar Radiation, 2019. [Online]. Available: https://eosweb.larc.nasa.gov/sse/.

[47] G. Pillai and H. A. Y. Naser, "Techno-economic potential of large scale photovoltaics in Bahrain," Sustainable Energy Technologies and Assessments, vol. 27, pp. 40-45, 2018, doi: 10.1016/j.seta.2018.03.003.

[48] M. Qolipour, A. Mostafaeipour and O. M. Tousi, "Techno-economic feasibility of a photovoltaic-wind power plant construction for electric and hydrogen production: A case study," Renewable and Sustainable Energy Reviews, vol. 78, pp. 113-123, 2017, doi: 10.1016/j.rser.2017.04.088. 